\title{
Effector and regulatory $B$ cells in immune-mediated kidney disease
}

\author{
Kristine Oleinikal ${ }^{l}$, Claudia Mauri ${ }^{l}$ and Alan D. Salama ${ }^{2 *}$ \\ ${ }^{I}$ Division of Medicine, University College London, London, UK \\ ${ }^{2}$ UCL Centre for Nephrology, Royal Free Hospital, London, UK \\ ${ }^{3}$ These authors contributed equally: Claudia Mauri and Alan D. Salama \\ *email: a.salama@ucl.ac.uk
}

[H1] Abstract B cells have a central role in many autoimmune diseases, including in those with renal involvement, as well as in the immunological response to kidney transplantation. The majority of studies of B cells have focused on their pathological role as antibody producers. However, these cells have broad functions in immune responses beyond immunoglobulin secretion, including antigen presentation to T cells and cytokine production. Importantly, not all B cell subsets enhance immune responses. Regulatory B (Breg) cells attenuate inflammation and contribute to the maintenance of immune tolerance. Breg cells are numerically deficient and/or dysfunctional in several autoimmune diseases that can affect the kidney, including systemic lupus erythematosus and anti-neutrophil cytoplasmic antibody-associated vasculitis, as well as in some groups of renal transplant recipients with alloimmune graft damage. B cell-targeting biologics have been trialled with promising results in diverse immune-mediated renal conditions. These therapies can affect both pro-inflammatory B cells and Breg cells potentially limiting their long-term efficacy. Future strategies might involve the modulation of inflammatory B cells in combination with the stimulation of regulatory subsets. Additionally, the monitoring of individual B cell subsets in patients may lead to the discovery of novel biomarkers that could help to predict disease relapse or progression.

\section{[H1] Introduction}

B cells contribute to immune-mediated diseases through diverse effector mechanisms, most notably via the production of antibodies, but also through antigen presentation leading to $\mathrm{T}$ cell activation and the secretion of various cytokines. The critical and clinically relevant role of B cells in autoimmune diseases is highlighted by the success of therapeutic B cell depletion in diseases such as antineutrophil cytoplasmic antibody (ANCA)-associated vasculitis (AAV) (1-3), cryoglobulinaemic glomerulonephritis (4), nephrotic syndrome including relapsing minimal change disease and membranous glomerulonephritis $(5,6)$. The role of $\mathrm{B}$ cell depletion in renal transplantation, as induction therapy or for management of antibody-mediated rejection, outside of its use in blood group-incompatible transplants, remains uncertain. 
Research in preclinical models together with insights from clinical studies of B cell depletion therapy have improved our understanding of the contribution of B cells to the aetiology and pathogenesis of immune-mediated diseases. Importantly, certain subsets B cells are capable of regulating immune responses and contributing to immune tolerance and are collectively referred to as regulatory B (Breg) cells . Current B cell depletion therapies target Breg cells as well as inflammatory B cells and to date, no specific means of clinically modulating inflammatory B cell subsets without impacting Breg cells have been developed. Moreover, human B cell subsets and their plasticity in disease states are only starting to be understood.

In this Review, we describe B cell functions with a focus on the roles of Breg cells in kidney diseases. We also discuss the application and potential adverse effects of $\mathrm{B}$ cell targeted therapies in autoimmune kidney diseases and renal transplantation.

\section{[H1] B cell development}

B cells display considerable phenotypic and functional diversity, with various subsets possessing specialised effector roles. B cell development begins in the foetal liver and continues in the bone marrow in which multiple checkpoints act to ensure that B cells released into the periphery express functional B cell receptors (BCR) and are not specific for self-antigens. The autoreactivity of a BCR is tested at the immature B cell stage, and the early bone marrow emigrant B lymphocytes are also referred to as transitional B cells. These immature B cells express surface IgM and IgD, and are often characterized by a $\mathrm{CD} 24^{\mathrm{hi}} \mathrm{CD} 38^{\mathrm{hi}}$ phenotype, and a lack of the memory B cell marker CD27 (7). Immature B cells complete their development in the periphery, giving rise to mature antigen-naïve $\mathrm{B}$ cells, identified as $\mathrm{CD} 24^{\text {int }} \mathrm{CD} 38^{\text {int }} \mathrm{CD} 27^{-}$B cells (FIG. 1). In response to antigen-specific stimulation, B cells can differentiate into plasmablasts, plasma cells and memory B cells (8).

Plasma cells are long-lived, terminally differentiated antibody-producing cells and plasmablasts are their short-lived proliferating counterparts. Collectively these cells, which lack expression of the panB cell marker CD20, are referred to as antibody-secreting cells. Plasma cells home to the bone marrow where they continuously produce antibody to provide immediate protection to the host upon re-infection. Memory B cells recirculate and can be rapidly induced to differentiate into antibodyproducing plasmablasts through interaction with cognate $\mathrm{T}$ cells. This memory response is typically more robust than the primary B cell response to antigen, and generates high affinity, class-switched immunoglobulins (9). Vaccination strategies capitalise on long-lived memory B cell responses and most successful vaccines rely on the mounting of an antibody response (10).

Enhanced understanding of B cell development and differentiation, as well as of their phenotypic and functional heterogeneity, may enable targeting of specific populations and monitoring changes in these populations may provide novel biomarkers for disease and treatment responses. 


\section{[H1] Effector functions of B cells}

B cells are key orchestrators of humoral immunity that can also influence $\mathrm{T}$ cell activation and tolerance through antigen presentation and cytokine secretion (FIG. 2). Early work in animals with congenital B cell deficiency generated contradictory results, with some studies reporting that the absence of $\mathrm{B}$ cells affected $\mathrm{T}$ cell responses, whereas others found no effect on $\mathrm{T}$ cells (11-13). Moreover, mice with congenital B cell deficiency were found to also have a number of additional immune defects that might have a direct impact on $\mathrm{T}$ cells, confounding analysis of the effects of $\mathrm{B}$ cell loss $(14,15)$. Thus, immunoglobulin-independent B cell functions have been deduced largely from investigating changes in $\mathrm{CD}^{+} \mathrm{T}$ cell responses following the transient depletion of $\mathrm{B}$ cells. For example, $\mathrm{T}$ cell subsets and $\mathrm{T}$ cell activation status were unaffected by $\mathrm{B}$ cell depletion in naïve mice (16). However, B cell depletion led to reduced T cell proliferation in response to antigen, as well as reduced memory responses to pathogens (16).

The existence of an antibody-independent contribution of B cells to immune responses is supported by the findings of animal studies in which B cells were unable to secrete antibody. For example, in the MRL/lpr model of lupus, B cells were able to contribute to disease pathogenesis in the absence of serum antibody (17). Similarly, in patients with rheumatoid arthritis (RA) benefit from rituximab, while greater in patients with circulating autoantibodies (anti-cyclic citrullinated peptide antibodies or rheumatoid factor), is still found in seronegative subjects, and six months following therapy, differences in response between seropositive and seronegative subjects are less marked (18). Below we discuss the evidence for inflammatory and pathogenic roles of antibodies, B cell-mediated antigen presentation and cytokine secretion, with a focus on immune-mediated kidney diseases and renal transplantation.

\section{[H2] Antibody production}

Autoimmunity is often characterized by the presence of self-reactive antibodies, for example, autoantibodies directed against nuclear antigens in SLE, neutrophil and monocyte antigens in AAV, glomerular basement membrane constituents in anti-glomerular basement membrane (GBM) disease and $\operatorname{IgG}$ antibodies to abnormally glycosylated $\operatorname{Ig}_{1}$ in $\operatorname{IgA}$ nephropathy (19-21). Autoantibodies are often used as disease markers, to define disease types or to monitor disease activity, and their pathogenicity in humans is often inferred from animal models or in vitro studies. Infrequently, direct pathogenicity of autoantibodies in patients is implied following placental transfer from an affected mother to the foetus $(22,23)$.

In transplantation, alloantibodies to polymorphic antigens such as human leucocyte antigens (HLA) are associated with poor long-term renal allograft outcomes (24-27). The role of alloantibodies in renal transplantation was initially recognised in the setting of hyperacute rejection owing to the 
presence of preformed blood group or HLA antibodies (28). In the clinic, hyperacute rejection has now been largely eliminated as a result of ABO-matching of donors and recipients, and rigorous screening of patient serum for anti-donor HLA antibodies prior to transplantation. Donor-specific IgG antibodies can however be formed de novo and contribute to transplant rejection. This finding implicates the germinal centre reaction in their production.

The class of an immunoglobulin determines its effector functions, including its ability to activate the complement system or to bind to immunoglobulin constant fragment $(\mathrm{Fc})$ receptors, so it can impact disease pathogenesis. For example, in kidney transplant recipients with donor-specific antibodies (DSA), acute antibody-mediated rejection was associated with C4d-fixing IgG3 DSAs, whereas patients who did not experience antibody-mediated rejection were found to have enrichment of IgG1 DSAs that lacked the ability to bind C1q (29). IgG subclasses are influenced by the nature of the antigen, T cell help and secondary signals such as TLR or cytokine receptor activation (30).

As mentioned previously, terminally differentiated plasma cells and plasmablasts do not express CD20, which is the antigen target of several monoclonal antibodies used for B cell depletion therapy. Interestingly, treatment with the anti-CD20 monoclonal antibody rituximab is associated with a clinically significant reduction in autoantibody levels in patients with RA and AAV $(3,31)$, despite its inability to directly target antibody-secreting cells. This effect is thought to result from the depletion of precursor cells that maintain the short-lived newly-differentiating plasmablasts, which are an important source of autoantibodies (32).

\section{[H2] Antigen presentation}

B cells are able to function as antigen presenting cells (APC) owing to their endocytic capacity, antigen processing ability and location in proximity to $\mathrm{T}$ cells within lymphoid organs (33). The binding of a specific antigen to an immunoglobulin receptor on the surface of a B cell leads to the capture, endocytosis and trafficking of that antigen to MHC class II-rich compartments. This favours the presentation of antigens that are taken up either by directly binding the BCR or associated with such antigens, and is in contrast to non-specific antigen loading found in myeloid lineage APCs. This mechanism may be particularly important for the presentation of antigens that are present in low quantities, such as autoantigens, and may in part explain the antibody-independent pathogenic role of B cells in autoimmune disease. Hence, B cell depletion can reduce effective antigen presentation and lead to attenuation of $\mathrm{T}$ cell activation and effector function. This attenuation underlies some of the effectiveness of B cell depletion therapy in various clinical settings (34).

In the context of chronic cardiac graft rejection, studies in murine models have demonstrated that B cells can support $\mathrm{T}$ cells in the alloimmune response and contribute to pathogenesis in an antibodyindependent manner $(35,36)$. Similarly, the ability of $\mathrm{B}$ cells to promote $\mathrm{T}$ cell activation through 
alloantigen presentation is observed in kidney transplant recipients with antibody-mediated rejection (37). In lupus-prone mice, B cells have been shown to act as APCs to elicit autoreactive T cell responses (38). Of note, B cells can also act as APCs to tolerise T cells, for example under conditions of non-BCR-mediated B cell antigen uptake (33).

\section{[H2] Cytokine production}

B cells are able to release an array of pro-inflammatory and anti-inflammatory cytokines that can polarize $\mathrm{T}$ cell responses. Most of our mechanistic understanding regarding the role of B cell cytokine production in immune responses comes from animal studies (39). Initial studies in mice showed that naïve B cells could be polarised in vitro in the presence of T helper type 1 (Th1) and Th2 cells to produce distinct effector cytokines (40). These polarised cells were termed B effector (Be) 1 and $\mathrm{Be} 2$ cells and were primed by IFN- $\gamma$ and IL-4, respectively. Be1 cells secreted predominantly type 1 cytokines (IFN- $\gamma$ and IL-12), whereas Be2 cells not only produced the type 2 cytokine IL-4, but also secreted high levels of IL-2, IL-6 and IL-10. Be1 cells could also be identified in vivo following the infection of mice with Toxoplasma gondii (type 1 response), whereas $\mathrm{Be} 2$ cells were identified following infection with Heligmosomoides polygyrus (type 2 response ) (40). The protective role of cytokine-producing B cells was demonstrated in the Heligmosomoides polygyrus infection model in which IL-2 secreted by Be2 cells was required for the maintenance of helminth-specific Th2 cells (41).

Be1 cells were originally thought likely to contribute to autoimmunity whereas $\mathrm{Be} 2$ cells were thought to have a role in allergic responses. However, human counterparts of these polarized cytokine-secreting subsets have not been identified. Nevertheless, accumulating evidence from studies in humans and mice implicate B cell pro-inflammatory cytokine production in disease pathology. In the murine model of multiple sclerosis (MS), termed experimental autoimmune encephalomyelitis (EAE), B cell depletion reduced disease severity only in those animals whose B cells were able to produce IL-6 (42). Similarly, in patients with MS who responded to rituximab, newly reconstituted B cells produced less IL-6 than those prior to B cell depletion following in vitro stimulation via the BCR, CD40 and TLR9 (42). Patients with MS also have increased frequencies of pro-inflammatory GM-CSF-producing memory B cells, which co-express IL-6 and TNF- $\alpha$ (43). The number of GM$\mathrm{CSF}^{+} \mathrm{B}$ cells in these patients was normalized upon B cell repopulation following B cell depletion therapy and this normalization was associated with a reduction in the myeloid pro-inflammatory response (43).

Whether B cell IL-6 production is broadly relevant to pathology in other autoimmune conditions has been called into question as IL-6 production by B cells in response to TLR9 ligands is reduced in patients with SLE compared to healthy individuals (44). Other pro-inflammatory cytokines, such as 
TNF- $\alpha$ and IFN- $\gamma$, that have been associated with immune-mediated pathologies affecting the kidney, including glomerulonephritis $(45,46)$, can be produced by B cells, particularly following infections.

B cells are found within structures with tertiary lymphoid tissue features (organised collections of $\mathrm{T}$ and B cells) in renal allografts (47) and their presence is associated with poor outcomes $(48,49)$ as well as in the renal interstitium in some patients with tubulointerstitial nephritis (50), AAV and SLE, where their numbers decrease with disease remission (51). However, these studies did not examine $\mathrm{B}$ cell cytokine production, and whether B cells found within the kidney secrete pro-inflammatory cytokines that might contribute to immune pathology remains to be determined.

\section{[H1] Regulatory B cells}

The term Breg cell is used to refer to B cells with a number of different phenotypes that, through an expanding array of mechanisms, act to suppress pathogenic $\mathrm{T}$ cell responses and thus support immune tolerance. However, Breg cells are most commonly defined as B cells that produce IL-10 and limit inflammation. These cells have been described in mice and in humans (52). To date, no unique Breg cell marker has been discovered and transcription factors that specifically drive the development of these cells have remained elusive.

\section{[H2] Development}

The ontogeny of Breg cells and how they relate to conventional B cell subsets remains to be established. However, it is likely that Breg cells can arise at various stages during B cell development and differentiation (FIG. 1), provided that the right environmental cues exist (53-55). Human Breg cells have been identified as minority populations within various B cell subsets including immature $B$ cells $\left(\mathrm{CD} 24^{\mathrm{hi}} \mathrm{CD} 38^{\mathrm{hi}}\right)(56)$, memory B cells $\left(\mathrm{CD} 24^{\mathrm{hi}} \mathrm{CD} 27^{+}\right)(57)$ and plasmablasts (58). Importantly, whether Breg cells that derive from different B cell developmental or activation stages are indeed ontogenically separate and whether these cells are equally suppressive is unknown. Even within the phenotypically defined $\mathrm{CD} 24^{\mathrm{hi}} \mathrm{CD} 38^{\mathrm{hi}}$ immature B cell subset in which Breg cells are enriched, functional differences exist in the proportions of pro-inflammatory and anti-inflammatory cytokines that cells can make. These differences might have important consequences for host immune reactivity.

Although most of the research on factors that drive Breg cell development has been conducted in mice, the signals that induce the differentiation of these cells in humans are also being uncovered. The available data suggest that unlike natural Treg (nTregs) cells, which constitute a separate lineage of $\mathrm{T}$ cells with a thymic origin, multiple Breg cell subsets can arise in the periphery in response to various cues, including binding to antigen receptors, CD40 and pattern-recognition receptors, in particular Toll-like receptors (TLR), as well as in response to inflammatory cytokines, all of which are elements of a successful immune response (59). In mice, Breg cell development, which leads to the suppression 
of Th17 cell responses, is dependent on the presence of pro-inflammatory cytokines such as myeloidderived IL-1 and IL-6 (54) as well as IL-21, which is produced by T cells (55). These cytokines that can induce Breg cells are all involved in Th17 cell polarisation and expansion, suggesting that this is a mechanism that contributes to immune homeostasis (60). Furthermore, in healthy individuals, low levels of IFN- $\alpha$ can drive Breg cell differentiation, whereas high levels of this pro-inflammatory cytokine lead to plasmablast differentiation, which no longer produce IL-10 (53). Moderate levels of inflammation therefore seem to contribute to Breg cell induction and maintenance, which contributes to restoration of homeostasis, whereas conditions of persistently high inflammation seem to inhibit the induction of Breg cells.

Of note, a requirement for BCR engagement in Breg cell development has been demonstrated using mice with limited BCR specificity or that lack critical molecules involved in BCR signalling (61). Taken together these data suggest that antigen-specific recognition, in addition to "homeostatic inflammation", is an important driver for Breg cell induction and IL-10 production. In murine models of MS, RA and inflammatory bowel disease (IBD) - (EAE, collagen-induced arthritis (CIA) and IBD respectively )- CD40 has been demonstrated to be important in the generation and function of Bregs $(59,62,63)$. CD40 stimulation enhances IL-10 production by murine B cells $(59,62)$. Mice with a B cell-restricted CD40-deficiency are unable to recover from EAE due to a defect in IL-10 production. Similarly in CIA the adoptive transfer of CD40-stimulated Bregs suppresses disease (62), and in the MRL/lpr model of lupus, anti-CD40 activated immature B cells supressed disease better than their unmanipulated counterparts upon adoptive transfer (64). CD40 has also been demonstrated to potentiate the in vitro suppressive capacity of human immature $\mathrm{CD} 24^{\mathrm{hi}} \mathrm{CD} 38^{\mathrm{h}} \mathrm{B}$ cells partially through increasing IL-10 (56). TLR agonists are potent inducers of IL-10 from murine and human B cells in vitro (65). While mice with global deficiency in the TLR adaptor protein MyD88 are resistant to EAE, mice with a B cell specific deletion of TLR2 and TLR4 or MyD88 develop chronic disease with associated inability to control the $\mathrm{T}$ cell inflammatory response (66). Lipopolysaccharide (LPS)induced Bregs have also been shown to suppress pancreatic inflammation in the non-obese diabetic (NOD) model of diabetes (67).

\section{[H2] Suppressive functions}

The ability of B cells to suppress $\mathrm{T}$ cell responses was first recognized in the 1970s in studies investigating inflammatory responses in animal models of delayed type hypersensitivity, where the absence of B cells led to exacerbation of the T cell-mediated immune reactions (23-25). However, it was the publication of three reports in the early 2000s that showed that B cells could suppress immune responses in murine models of autoimmunity, namely inflammatory bowel disease (63), EAE (59) and CIA (62), that challenged the paradigm of B cells as perpetrators of autoimmune pathology. These studies showed that Breg cells could suppress disease manifestations and modulate inflammation and 
that these effects were dependent on the production of IL-10. Subsequently, IL-10-producing B cells were shown to modulate disease in murine arthritis models via suppression of Th1 and Th17 cell responses $(68,69)$. These studies also found that Breg cells promote the expansion of Treg cells and enhance their expression of the transcription factor FoxP3. This finding is consistent with previous observations of reduced Treg cell numbers in B cell-deficient mice (70, 71). Data suggest that in mice, plasmablasts produce considerable amounts of the regulatory cytokine IL-10, and represent IL-10+ Bregs with plasmablast phenotype (58). Plasmablasts producing another immunomodulatory cytokine IL-35 have also been identified in mice, in which they contribute to suppression of inflammation, but these cells did not co-produce IL-10 (72). Interestingly, IL-35 has been demonstrated to promote IL10 production by human B cells through a positive feedback loop, contributing to the amplification of this suppressive pathway (73). Matsumoto et al. identified IL-10-producing plasmablasts in EAE, Shen et al. discovered that IL-35 is a cytokine that is involved in immune suppression by B cells, but IL-35- and IL-10-producing B cells corresponded to different populations in their hands. Finally, Wang et al. showed that IL-35 and IL-10 can be produced by the same cells, but these were of CD5+CD19+B2201o Breg.

Human IL-10-producing B cells have been identified not only in the context of autoimmunity but also in infection and cancer. These cells can be beneficial in the setting of autoimmunity as they suppress inflammatory responses through the inhibition of $\mathrm{T}$ cells and myeloid cells; however, in the context of infection or cancer they have been shown to contribute to pathology as they hinder protective immunity against viral pathogens and neoplasms (74). Deficiencies in Breg cell number and suppressive function have been reported in a variety of autoimmune conditions, including SLE (56, 75), RA (76), MS (77) and psoriasis (78).

The immature Breg cell subset $\left(\mathrm{CD} 19^{+} \mathrm{CD} 24^{\mathrm{hi}} \mathrm{CD} 38^{\mathrm{hi}}\right)$ can regulate $\mathrm{T}$ cell activation (as evidenced by a reduction in $\mathrm{T}$ cell production of IFN- $\gamma$ and TNF- $\alpha$ ) in an IL-10-dependent manner (56). Importantly, these Breg cells are functionally impaired in patients with SLE and other autoimmune conditions (56). In patients with active RA, CD24hi $C D 38^{\text {hi }}$ Breg cells were not only reduced in number but were also less able to inhibit Th17 cell polarisation and promote Treg cell induction than those from healthy individuals and patients with inactive RA (76). Together, these results suggest that autoimmunity may in part be driven by an inability of Breg cells to inhibit an autoreactive immune response.

A second population of IL-10-producing Breg cells, termed B10 cells was initially identified as a functionally distinct subset in mice but has now also been described in human peripheral blood (57). Phenotypically, in humans these cells are mostly found within the memory B cell population $\left(\mathrm{CD} 19^{+} \mathrm{CD} 24^{+} \mathrm{CD} 27^{+}\right)$and they suppress monocyte inflammatory cytokine production in an IL-10dependent manner in vitro (57). Patients with common variable immunodeficiency, who may develop 
autoimmune diseases, have reduced Treg cell function and reduced numbers of IL-10-producing B cells however, the Treg cell defect did not correlate directly with the loss of Breg cells (79).

Human Breg cells have also been reported to modulate $\mathrm{T}$ cell responses via mechanisms other than IL-10 production, for example via the immunomodulatory cytokine TGF- $\beta$, via indoleamine 2,3dioxygenase (IDO), which alters $\mathrm{T}$ cell activation through breakdown of the essential amino acid tryptophan, via programmed death ligand 1 (PD-L1), which engages the inhibitory receptor PD-1 on T cells (80-82), and through combined IL10 and IgG4 secretion(83)(TABLE1). Breg cells might also have the capacity to induce $\mathrm{T}$ cell death through the action of granzyme $\mathrm{B}$ (GzmB) (84), which is secreted by $\mathrm{CD} 19^{+} \mathrm{CD} 38^{+} \mathrm{CD} 1 \mathrm{~d}^{+} \operatorname{IgM}{ }^{+} \mathrm{CD} 147^{+} \mathrm{B}$ cells and is upregulated by IL-21, which is made by various T cell subsets (84). Of note, the cell surface marker CD1d, which is expressed on many of the identified Breg subpopulations in mice and humans has a role in the presentation of lipids to invariant natural killer T (iNKT cells $(75,85)$. Although iNKT cells have dual roles in immunity, they are increasingly associated with immune regulation in the context of autoimmune disease (86). CD1d expression by Breg cells contributes to the regulation of inflammation in mice, independently of IL-10 (87). s

In summary, Breg cells can be found within various B cell subsets and have the ability to regulate other immune cells within complex inflammatory circuits (TABLE 1).

\section{[H1] B cells in kidney disease}

Breg cells have now been studied in a variety of diseases that affect the kidneys, including SLE, $\mathrm{AAV}$, and other connective tissues diseases, as well as in the context of renal transplantation. No two diseases appear to have identical Breg abnormalities, which can be reduced in numbers, functionally, defective or both. Breg cells have also been proposed as potential biomarkers of disease activity that might be used to predict immune quiescence or future relapses (TABLE 2).

Many diseases that lead to kidney dysfunction (such as anti-GBM disease, SLE and AAV) are defined by, or associated with, the presence of autoantibodies. Moreover, some kidney diseases that do not have a clear autoantibody phenotype, such as minimal change disease or focal segmental glomerulosclerosis (88), seem to respond to immunomodulatory therapy, suggesting a contribution of immune dysregulation to their pathogenesis (88).

As discussed above, B cells promote autoimmunity by producing pathogenic autoantibodies and proinflammatory cytokines and by activating self-reactive $\mathrm{T}$ cells through the presentation of selfantigens (89). Consequently, in autoimmune conditions, treatment is often directed at immediate removal of antibodies (using plasmapheresis) or interference with their action (using intravenous immunoglobulins) as well as long-term suppression of $\mathrm{B}$ and $\mathrm{T}$ cell reactivity to prevent further 
expansion and activation of self-reactive leukocytes. However, a more nuanced understanding of immune regulatory circuits has highlighted the impact that these therapies have on Treg cells and Breg cells with potential short-term and long-term effects on disease pathogenesis.

Similarly, although alloreactive B cells are considered harmful in renal transplantation, settings exist in which in vitro B cell depletion results in enhanced alloreactivity, suggesting a potential regulatory role (37). Importantly, end stage renal disease is associated with changes in B cell immunity as evidenced by the finding that patients fail to mount robust responses to vaccinations (90). Reports also exist of skewed $\mathrm{B}$ cell subpopulations in patients on dialysis, with reduced levels of $\mathrm{CD} 24^{+} \mathrm{CD} 38^{-}$ memory B cells and elevated levels of $\mathrm{CD} 24^{\text {hi }} \mathrm{CD} 38^{\text {hi }}$ immature B cells compared to pre-dialysis patients and healthy individuals (90). Moreover, higher serum levels of IL-10 and IL-4 are found in patients on dialysis than in those pre-dialysis (90). Such changes mean that analyses of cell subsets among patients with autoimmune kidney disease should ideally take renal function into account and use appropriately matched case controls, which are often lacking.

\section{[H2] Kidney transplantation}

In experimental and clinical transplantation, Breg cells seem to have a role in maintaining graft function and in reducing the risk of DSA production. In a cohort of renal transplant recipients operational tolerance was associated with a B cell-gene transcriptional signature and augmented B cell numbers $(91,92)$. Tolerant transplant recipients had increased numbers of total and naïve (CD27$\operatorname{IgM}^{+} \operatorname{IgD}{ }^{+}$) B cells in their peripheral blood compared to stable transplant recipients on maintenance immunosuppression. Tolerance was also associated with an increase in the levels of IL- $10^{+}$immature B cells and increased levels of CD20 mRNA in the urine (91). The increased frequency of immature B cells in peripheral blood and enhanced IL-10 production by total B cells following in vitro culture was confirmed in a different cohort of operationally tolerant transplant recipients (93).

Another study documented an augmented population of IL-21-dependent GzmB-expressing B cells in tolerant patients compared to those with stable function on immunosuppressants. These B cells suppressed $\mathrm{CD}^{+} \mathrm{T}$ cell activation by inducing apoptosis and inhibiting proliferation (94). This regulation was mediated through a direct $\mathrm{T}$ cell contact-dependent action of GzmB, and not by IL-10 or TGF- $\beta$. However, a 2016 analysis of validation cohorts of tolerant renal transplant recipients suggested that many of the earlier reported differences were confounded by the fact that certain immunosuppressive medications that were used in the non-tolerant cohort have direct effects on B cell subsets, including modulation of gene expression (95). For example, both glucocorticoids and azathioprine can substantially reduce the numbers of immature B cells, whereas calcineurin inhibitors do not have this effect (TABLE 3). Nevertheless, when immunosuppression-independent gene sets were analysed, a panel of nine genes, including BCL2A1, EEF1A1 and IGLC1, which are also 
expressed in B cells, was found to be highly predictive of the tolerant state (95). Importantly, in a cohort of operationally tolerant liver transplant recipients, a different set of transcripts - those expressed by CD56 ${ }^{+}$lymphocytes (NK and T cells) - were significantly over-represented (96), which may reflect differences in tolerogenic pathways between these organs.

In addition to operationally tolerant patients, B cell populations and graft outcomes have been investigated in cohorts of transplant recipients on continuous immunosuppression. Higher numbers of $\mathrm{CD} 24^{\mathrm{hi}} \mathrm{CD} 38^{\mathrm{hi}} \mathrm{IL}-10$-producing Breg cells have been found in patients with longer duration of graft survival (97) and in those with fewer rejection episodes (98, 99), suggesting that these cells might be of use either as a biomarker for improved graft outcomes or as a therapeutic intervention. Prospective studies have reported increased numbers of IL-10- and GzmB-expressing B cells in patients with stable grafts over the first year of transplantation (100). Interestingly, CD24 ${ }^{\text {hi }} C D 38^{\text {hi }}$ immature B cells with the highest IL-10:TNF- $\alpha$ ratio were enriched in patients with stable graft function, whereas in patients with chronic rejection, immature B cells had equivalent levels of IL-10 but higher levels of TNF- $\alpha$ (101). The lower IL-10:TNF- $\alpha$ ratio correlated with poorer three-year graft outcome and these cells were shown to be functionally less suppressive of Th1 responses than those with higher IL10:TNF $\alpha$ ratio (101). Further validation of these cells as biomarkers and the potential for their therapeutic manipulation is currently being investigated.

The impact of immunosuppressive agents on Breg cell populations has also been investigated in other transplant cohorts with some contradictory findings (TABLE 3). For example, different agents used as induction therapy result in different proportions of Bregs. Induction with alemtuzumab (a depleting monoclonal antibody directed against CD52, which is present on many leukocyte populations including $\mathrm{B}$ cells) augmented naïve, immature and $\mathrm{CD}^{+} \mathrm{CD} 1 \mathrm{~d}^{\text {hi }} \mathrm{B}$ cell numbers following repopulation, to a greater extent than did basiliximab (an anti-CD25 antagonist), and the alemtuzumab-treated patients had improved graft outcomes and lower levels of DSAs (102).

In ABO-incompatible renal transplant recipients, treatment with rituximab resulted in a predominantly naïve B cell phenotype upon B cell repopulation (containing a greater proportion of IL-10-producing Breg cells) 1 year following transplantation (100). In contrast, another study reported increased rates of acute transplant rejection following rituximab induction therapy (103), possibly due to depletion of Breg cells, which express CD20, but this finding has not been universal in other rituximab studies $(104,105)$. Results from ongoing trials of rituximab as induction therapy are awaited. With regards to maintenance therapy, patients treated with sirolimus or calcineurin inhibitors, had reduced numbers of CD24 ${ }^{\text {hi }}$ CD $38^{\text {hi }}$ IL-10-secreting Breg cells in comparison to healthy controls $(97,106)$. These findings suggest that certain immunosuppressive agents may have greater effects on the Breg cell population than others. 
Patient stratification based on Breg cell populations needs to be validated prospectively, and perhaps optimised for clinical ease of use, as IL-10 detection is currently complex, but could provide a rationale for augmenting or reducing immunotherapy at an early stage to improve graft outcomes and reduce the burden of immunosuppression in those more likely to benefit. In addition, strategies that augment Breg cell numbers or function in renal transplant recipients may be beneficial in maintaining long-term graft function, reduce the generation of alloantibodies and perhaps facilitate the restoration of tolerance.

\section{[H2] Systemic vasculitis}

Small vessel pauci-immune AAV is frequently characterised by ANCA, which is an autoantibody directed against neutrophil and monocyte proteins. This disease often results in renal involvement, with a proportion of patients progressing to end-stage renal disease. B cell involvement is common in proteinase-3 (PR3)-ANCA-associated disease and is evidenced by the clinical success of anti-CD20 antibody-mediated B cell depletion in both induction and maintenance therapy (1-3). Limited reports of benefit of anti-CD20 in ANCA negative systemic vasculitis also exist, suggesting a mechanism of action beyond antibody reduction (107). Importantly, in AAV, B cells are found at the sites of inflammation - within inflamed kidneys (108) and inflammatory granulomatous lesions (109).

The role of Breg cells in mediating AAV remission, their potential use as biomarkers of stable disease and more broadly the use of B cell subset distribution as a possible predictor of future relapses, have all been studied in various single centre cohorts and clinical trials. An important caveat is that different groups have used distinct surface markers for the characterization of Breg cells, with only some studies focusing on IL-10 production and few analysing functional suppressive capability. Overall, it is difficult to unequivocally demonstrate that the increase in Breg cells that is observed in patients with AAV during remission, compared to patients with active disease, is responsible for disease inhibition, especially if the effects of immunosuppressive medications are not taken into account (110) (TABLE 3).

In patients with AAV who have untreated active disease, numerical deficiencies have been reported in several $\mathrm{B}$ cell subsets that were previously described to contain cells with regulatory functions $\left(\mathrm{CD} 24^{\text {hi }} \mathrm{CD} 38^{\text {hi }}\right.$ and $\mathrm{CD} 27^{+} \mathrm{CD} 38^{\text {lo }} \mathrm{B}$ cells) and in the overall frequency of IL- $10^{+} \mathrm{CD} 19^{+} \mathrm{B}$ cells when compared to healthy individuals (111-113) and to patients in remission $(112,113)$. Conversely, an increase in the frequency of IL-10-producing Breg cells has been reported following B cell repopulation in patients treated with rituximab, suggesting that CD20 depletion is effective in restoring the balance between effector B cells and Breg cells whilst achieving remission. In these studies, assessment of the cytokine profile of repopulating B cells has been proposed as a predictor of 
disease relapse $(112,114)$. Other studies have used the co-expression of CD19 and CD5 as surrogate Breg cell markers. This $\mathrm{CD}^{+} \mathrm{B}$ cell population has been shown to produce IL-10 (115). CD19 ${ }^{+} \mathrm{CD} 5^{+}$ $\mathrm{B}$ cell numbers decrease during acute AAV but increase to normal during disease remission (116). Following rituximab therapy, patients with normalized $\mathrm{CD} 19^{+} \mathrm{CD}^{+} \mathrm{B}$ cell frequencies in repopulating $\mathrm{B}$ cells experienced longer time to relapse, compared with those whose $\mathrm{CD} 19^{+} \mathrm{CD}^{+} \mathrm{B}$ cells did not repopulate to the same extent (117). However, the predictive utility of measuring $\mathrm{CD} 19^{+} \mathrm{CD}^{+} \mathrm{B}$ cell numbers for assessment of disease relapse following either rituximab or conventional cyclophosphamide-based therapy was not validated in an analysis of data from the RAVE trial (3). In fact, the number of $\mathrm{CD}^{+} \mathrm{B}$ cells was found to be highly variable from the time of acute disease to remission and no association with subsequent relapses was observed (118).

\section{[H2] SLE}

SLE was one of the first human diseases in which autoimmunity was found to be associated with a number of abnormalities in B cell subsets including dysfunction of Breg cells (56). Patients with SLE present with polyclonal B cell activation, elevated immunoglobulin levels and various autoantibodies (119). Moreover, genetic studies of patients with SLE have identified polymorphisms in genes that influence B cell development, activation and signalling, leading to the development of autoreactive B cells (120) and animal models have further confirmed a key role for B cells in disease pathogenesis (120) .

Paradoxically, clinical trials of B cell depletion agents have not demonstrated benefit in SLE (121, 122). Nevertheless, the targeting of B cell survival through B cell activating factor (BAFF) inhibition has shown some success for the treatment of less severe disease manifestations, such as skin and joint manifestations in certain trials $(123,124)$. The failure of rituximab and certain BAFF inhibitors in some SLE trials is in contrast to clinical experience and treatment guidelines (125). Numerous reasons for these failed trials have been proposed, including the liberal additional use of glucocorticoids to treat patients (potentially masking a beneficial impact of rituximab) and the inability of rituximab to successfully deplete tissue memory B cells (125).

Clinical data have shown that IL- $10^{+} \mathrm{B}$ cells inversely correlate with lupus activity (56). Although the numbers of $\mathrm{CD} 19^{+} \mathrm{CD} 24^{\text {hi }} \mathrm{CD} 38^{\text {hi }} \mathrm{B}$ cells are comparable between healthy controls and patients with SLE, the proportion of these cells that produce IL-10 is decreased in patients with SLE, particularly in those with lupus nephritis (98). This defect in IL-10 production leads to a reduced ability of $\mathrm{CD} 19^{+} \mathrm{CD} 24^{\text {hi }} \mathrm{CD} 38^{\text {hi }} \mathrm{B}$ cells from patients with SLE to inhibit Th1 responses compared to those of healthy individuals (56). In addition, the frequency of IL-10-producing cells within the naïve B cell pool $\left(\mathrm{CD} 19^{+} \mathrm{CD} 27^{-} \mathrm{CD} 38^{\text {int }} \operatorname{IgD}{ }^{+} \mathrm{B}\right.$ cells $)$ is reduced in patients with SLE and these cells express higher levels of co-stimulatory molecules than those from healthy individuals leading to enhanced $\mathrm{T}$ cell activation (126). Although IL-21 usually drives Breg cell differentiation, in patients with SLE it 
promotes a population of $\mathrm{CD} 11 \mathrm{c}^{+}$Tbet $^{+}$memory B cells that can differentiate into short lived plasma cells and this memory population correlates with disease activity (127).

Finally, patients with SLE can have defects in iNKT cell numbers and function $(75,128-130)$, which may be due to abnormalities in B cells capable of presenting lipid antigens to iNKT cells. In particular, B cells from patients with SLE also have aberrant CD1d endocytic recycling compared to healthy controls (75). CD1d expression is normalised on newly repopulating immature B cells in patients that respond to rituximab therapy, and interestingly, this CD1d restoration correlates with the normalisation of iNKT cell numbers and function. The association of clinical improvement with the restoration of Breg cell function could potentially be a useful marker of immunosuppression adequacy (see TABLE 2).

Other complex self-regulatory circuits that operate in healthy individuals are compromised in patients with SLE. For example, in healthy individuals a negative feedback loop exists in which IFN- $\alpha$ secreted by plasmacytoid dendritic cells (pDCs), in addition to driving plasmablast differentiation (131, 132), also induces the production of IL-10 by Breg cells, contained mostly within the $\mathrm{CD} 24^{\mathrm{hi}} \mathrm{CD} 38^{\mathrm{hi}}$ immature B cell subset (53). These Bregs in turn inhibit further IFN- $\alpha$ production by pDCs in an IL-10-dependent manner (53). In patients with SLE, pDCs are hyperactivated, and promote plasmablast differentiation, but not the induction of $\mathrm{CD} 24^{\mathrm{hi}} \mathrm{CD} 38^{\mathrm{hi}} \mathrm{Bregs}(53)$. This effect is at least in part driven by alterations in STAT1 and STAT3 signalling in immature B cells (53). Although individual B cells can secrete TNF- $\alpha$ and IL-6, as well as IL-10, selective skewing of this balance may be beneficial and has been achieved in vitro using epratuzumab (133). This antibody binds to CD22 and inhibits B cell receptor-mediated activation in healthy individuals and in patients with SLE. This inhibition leads to reduced B cell proliferation and pro-inflammatory cytokine production, skewing the cytokine balance towards IL-10 production (133).

Changes in the B cell populations following rituximab therapy in SLE patients with delayed reconstitution of peripheral memory $\mathrm{B}$ cells and greater repopulation of immature B cells are associated with prolonged disease remission, compared with patients in whom peripheral memory B cells returned sooner and there were less immature B cells. This ratio of immature and memory B cells may provide a useful biomarker to decide on the need for rituximab re-dosing to prevent subsequent disease flares (TABLE 2) (134).

\section{[H2] Other immune complex-mediated disorders}

B cell depletion therapy has been shown to be effective in various other immune complex-mediated renal disorders including cryoglobulinaemia (4) and IgG4-related disease (IgG4-RD) (135). Anecdotal reports of benefit in fibrillary nephropathy (136), IgA nephropathy and IgA vasculitis (HenochSchonlein purpura) (137) also exist. 
In comparison to healthy controls, patients with hepatitis $\mathrm{C}$ virus (HCV)-associated cryoglobulinaemia present with various immune perturbations, including reductions in the numbers of both naïve and memory B cells as well as Treg cells, elevated numbers of T follicular helper (Tfh) and Th17 cells, and increased serum BAFF levels (138). However, following rituximab therapy, B cell, T cell and monocyte-related genes, including TWEAK receptor, CCR2 and interferon-stimulated genes are downregulated (138). BAFF levels also increase following rituximab therapy, but more so in patients with subsequent relapse compared with those who do not (138). In HCV-associated cryoglobulinaemia, a reduction in viral load normalises immune dysregulation and patients who are treated with direct antiviral therapy alone (without rituximab), have an increase in PD-1-expressing B cells and Treg cells, as well as a reduction in Tfh, Th17 and CD2 $1^{\text {low }}$ memory B cells (139).

In patients with IgG4-RD, investigation of B cell subsets identified a reduction in the frequency of immature B cells $\left(\mathrm{CD} 19^{+} \mathrm{CD} 24^{\text {hi }} \mathrm{CD} 38^{\text {hi }}\right)$ and lower BAFF receptor expression, whereas memory B cell and plasmablast numbers were increased compared to healthy controls (140). No functional studies of B cells were undertaken but, interestingly, serum IL-10 levels were higher in patients with IgG4-RD than in healthy individuals $(140,141)$. This finding may be explained by the observation that IgG4 production is enriched in a subset of IL-10-producing Breg cells that express CD71 and CD25, suggesting that in this setting Breg cell subsets might contribute to disease through antibody production (83). B cell depletion with rituximab has been reported to be of benefit in IgG4-RD, and results in a significant reduction in the levels of plasmablasts $\left(\mathrm{CD} 19^{\text {low }} \mathrm{CD} 38^{+} \mathrm{CD} 20^{-} \mathrm{CD} 27^{+}\right)$and $\mathrm{IgG} 4$. However, changes in the levels of other B cell subsets were not examined (135, 141). Plasmablast numbers return to baseline levels at the time of relapse, suggesting that they may be a biomarker of disease activity and have a role in disease pathogenesis (141).

In, patients with IgA nephropathy reduced $\mathrm{CD} 19^{+} \mathrm{CD} 5^{+} \mathrm{CD} 1 \mathrm{~d}^{+} \mathrm{IL}-10^{+}$Breg cell frequency was found compared to healthy controls (142). However, an open label study of rituximab added to standard care demonstrated no benefit with regards to renal function or proteinuria, despite B cell depletion, and similarly had no effect on the levels of pathogenic antibodies against galactose-deficient IgA1 (143). In contrast, in a case series of patients with $\operatorname{IgA}$ vasculitis, rituximab therapy allowed steroid minimisation and led to improved Birmingham Vasculitis Activity Scores (BVAS) and reduction in proteinuria in the majority of patients; however, a third of patients relapsed (137). Data on B cell subsets and reconstitution following B cell depletion were not available.

\section{[H2] Nephrotic syndromes}

B cell depletion strategies have enabled dissection of the functional role of B cells in various nephrotic states. In membranous glomerulonephritis, rituximab therapy is effective in two-thirds of patients and is presumed to act through a reduction in the levels of pathogenic anti-phopspholipase A2 receptor (PLA2R) or anti-thrombospondin type 1 domain containing 7A (THSD7A) antibodies (144). 
Significant increases in Treg cells following rituximab therapy in responders have also been noted (145). Rituximab seems to have similar efficacy to cyclophosphamide for inducing complete remissions, less so for partial remissions, and a better safety profile (146).

In relapsing or steroid-dependent minimal change disease, rituximab has been used with anecdotal success, and its effects may be in part through the direct inhibition of downregulation of podocyte sphingomyelin phosphodiesterase acid-like $3 \mathrm{~b}$, resulting in stabilisation of the actin cytoskeleton and preventing podocyte apoptosis (5). Moreover, rituximab might have an indirect effect in normalising Treg/Th17 cell and CD4/CD8 T cell imbalances found in active disease in a B cell-dependent manner (6). A study reported that paediatric patients with frequently relapsing or steroid-dependent nephrotic syndrome had lower baseline frequencies of immature and mature B cells than age-matched healthy controls (147). Nevertheless, the researchers found that it was the delayed repopulation by classswitched memory B cells that was protective against disease relapse (as in SLE), again suggesting that depletion of memory B cells is therapeutic. A pathogenic role of B cells is consistent with data from a $\mathrm{B}$ cell-dependent in vivo mouse model of proteinuria in which podocyte damage was dependent on B cell-derived IL-4 (148). This cytokine is expressed at high levels by lymphocytes from paediatric patients with minimal change nephrotic syndrome when stimulated ex vivo (149).

\section{[H1] Targeting B cells}

Specific targeting of B cells rather than generalised leukocyte ablation using agents such as cyclophosphamide, was introduced for the treatment of B cell lymphomas and leukaemias, and was capitalised on for the treatment of conditions with an autoantibody component such as RA (150). Diverse B cell surface markers and growth factors have been selected to generate monoclonal antibodies that target B cells (FIG. 3) and exert various clinical effects.

CD20 is the target of a number agents including rituximab, which depletes cells through complementdependent and complement-independent pathways (151). Other B cell-directed biologic therapies include epratuzumab, which targets CD22, a lectin found on mature and some immature B cells, alemtuzumab which targets CD52, a glycoprotein that is highly expressed on B and T cells and at lower levels on myeloid cells, and MEDI-551, which targets CD19, a surface protein that regulates BCR signalling and is found on all B cells $(152,153)$. In addition, critical B cell growth factors, such as BAFF (also termed B lymphocyte stimulator) and a proliferation-inducing ligand (APRIL) have been targeted in their soluble forms using agents such as belimumab, tabalumab, blisibimod and atacicept (124) . These growth factor pathways can also be targeted by the use of GSK2857916, which inhibits B cell maturation antigen (BCMA), a receptor for BAFF and APRIL.

B cell targeting therapies are now being tested in combination, for example rituximab has been used with belimumab in clinical trials to treat patients with SLE and Sjogren's syndrome (154-157). The 
rationale for the use of this combination is that, following depletion of B cells with rituximab, levels of BAFF increase and may contribute to B cell differentiation and activation following repopulation (158). In addition, elevated BAFF levels may promote long-lived plasma cells. In patients with primary immune thrombocytopenia, antibody-secreting cells were the major splenic B cell population that was resistant to rituximab. In patients who had not received rituximab, antibody-secreting cells were predominantly short-lived plasmablasts, whereas in treatment-refractory patients they were phenotypically long-lived plasma cells (159). This finding suggests that following B cell depletion the ensuing cytokine milieu, including increased BAFF levels, may promote the generation of long-lived plasma cells. Use of both rituximab and belimumab may therefore prevent the establishment of such long-lived plasma cells, but this hypothesis remains to be tested.

B cell depletion and/or modulation therapy is an expanding field with numerous novel B cell-targeting monoclonal antibodies being generated and new rituximab biosimilars coming into the clinical arena (160). Differences in the B cell populations targeted will have an impact on the degree of B cell depletion, the efficacy of the therapy, autoantibody production and potentially adverse effects (161). Notably, B cell depletion agents directed at CD20 or CD22 do not target plasma cells and plasmablasts, which lack expression of these cell surface markers. Nevertheless, in patients with RA or AAV, B cell depletion with these treatments is associated with a reduction in autoantibody levels, presumably through reduced maturation of B cells to plasmablasts and short-lived plasma cells, which are important sources of autoantibodies (31). Direct targeting of plasma cells with high dose glucocorticoids and proteasome inhibitors has also been attempted in alloimmune and autoimmune diseases. For example, the BORTEJECT trial in late antibody-mediated transplant rejection, which showed no benefit of bortezomib, a proteasome inhibitor, which prevents degradation of misfolded proteins by proteasomes, with their subsequent accumulation leading to cell cycle arrest and apoptosis in highly secretory cells(162), and the ongoing TAVAB trial of bortezomib in various refractory autoantibody diseases, including SLE, RA and myasthenia gravis, looking for changes in autoantibody levels following drug therapy (163). The use of combinations of rituximab and proteasome inhibitors in resistant autoimmune diseases have been reported in small case series of various autoantibody-mediated haematological diseases, demonstrating efficacy in $77 \%$ of cases and complete remission in 38\% (164). Novel anti-CD38 monoclonal antibodies that specifically target plasma cells are being tested in multiple myeloma (165) and may prove useful in antibody-mediated autoimmune diseases. Finally, chimeric antigen receptor (CAR)-T cells, which are engineered to target specific antigens, including CD19 or CD22, have emerged as effective B cell depletion therapies in the setting of B cell haematological malignancies (166). Similar therapies aimed at antigens that could discriminate between memory and regulatory B cells may offer hope for more targeted B cell therapy in the future. A proposed mechanism explaining the impact of B cell targeting 
strategies and the subsequent immune changes in autoimmunity and transplantation is shown in Figure 4.

\section{[H1] Adverse effects of B cell depletion}

B cell depletion agents are increasingly used across a number of disease states. Although generally safe with regards to risk of infection and malignancies, their use is associated with some important adverse effects. Particular agents may affect some B cell subpopulations more than others resulting in different types of immune responses, which may impact on the range and severity of adverse effects. Non-B cell depleting agents can also impact B cell subsets, raising the possibility that particular drug combinations could be used to increase the ratio of Breg cells to inflammatory B cells (167). Following a dose of rituximab (with additional tacrolimus and mycophenolate), CD20-expressing B cells are effectively depleted from the circulation, nevertheless some $\mathrm{CD} 19^{+} \mathrm{CD} 20^{-} \mathrm{B}$ cells persist most of which are memory B cells (168). By contrast, in the lymph nodes, the total number of B cells is unaltered, $\mathrm{CD} 20^{+}$naïve and some memory B cell subsets are reduced, but populations of $\mathrm{CD} 19^{+} \mathrm{CD} 20^{+}\left(\mathrm{IgD}^{-} \mathrm{CD} 27^{+}\right.$and $\left.\mathrm{IgD}^{-\mathrm{CD}} 27^{-}\right)$memory cells are unchanged. Tfh cells, which are essential to provide help for B cell differentiation into memory cells and plasma cells, are also unaffected (168). This tissue resistance to rituximab may underlie some of its safety, as memory responses to infectious organisms may be preserved, and potentially explain its more modest effect in SLE, where $\operatorname{IgD} \mathrm{CD}^{-} 7^{+}$and $\mathrm{IgD}^{-} \mathrm{CD} 27^{-}$memory cells are expanded (169). Similarly, epratuzumab seems to deplete a greater proportion of $\mathrm{CD} 27^{-}$naïve cells than $\mathrm{CD} 27^{+}$memory cells, although this effect might not be its main mode of action. Epratuzumab inhibits IL- 6 and TNF- $\alpha$ production in vitro, but IL-10 production is unaffected. This effect on cytokine production contributes to a regulatory cytokine environment, but a specific impact on Breg cells has not been described (170).

Depletion of B cell subsets can lead to reduced T cell activation and in turn loss of viral surveillance. Consequently, reactivation of viruses can occur, particularly in the case of hepatitis B infection in which a significant number of patients can reactivate more than 6 months after their last dose of rituximab (171). Current guidelines suggest the use of prophylaxis with antivirals in such patients (171). A small number of cases of progressive multifocal leukoencephalopathy, related to JC virus infection, have also been reported in patients treated with rituximab either alone or following other immunosuppressive therapies (172). Patients should be counselled about this risk for which no obvious preventative strategy exists at present.

Hypogammaglobulinaemia following B cell depletion therapy or targeting of B cell growth factors is common, occurring in 30-56\% of patients with AAV after rituximab treatment $(173,174)$, and in up $2 \%$ of patients with SLE in the first year of belimumab therapy with levels falling by a median of $13 \%$ after 4 years of treatment (175). Total dose exposure of rituximab therapy may not predict hypogammaglobulinaemia, as this effect is more likely to be related to the duration of B cell depletion 
(174). In the case of belimumab, IgG levels decrease in the first year of therapy but stabilise thereafter (175). Infection susceptibility is related to the severity of hypogammaglobulinaemia and can be established functionally by assessing responses to vaccination, and modulated by use of intravenous immunoglobulin replacement (174).

The future introduction of rituximab biosimilars, and other B cell depletion agents, might lead to different adverse effects, which should be carefully assessed. Rituximab infusion reactions occur in approximately $25 \%$ of patients with RA, and anti-drug antibodies (ADA) in $11 \%$ (176). Immunogenicity is increasingly recognised as a potential impediment to the safety and efficacy of biological therapy, but a rigorous evaluation of the incidence as well as of the clinical consequences of ADA is still awaited.

\section{[H1] Conclusions}

B cell targeting therapies are effective in many systemic diseases that affect the kidney, as well as in renal transplantation. Nevertheless, the lack of efficacy in certain conditions emphasizes the complex roles of B cells in immune-mediated disease states. In addition to the pathogenic roles of B cells in autoimmune kidney disease and transplantation, B cells with regulatory properties can arise during an inflammatory response and serve to limit such a response. Various Breg cell subsets have been described with these properties, including IL-10-producing $\mathrm{CD} 19^{+} \mathrm{CD} 24^{\mathrm{hi}} \mathrm{CD} 38^{\mathrm{hi}}$ immature $\mathrm{B}$ cells and $\mathrm{CD} 19^{+} \mathrm{CD} 24^{+} \mathrm{CD} 27^{+}$memory B cells. Breg cells have been studied in various immune-driven renal diseases and shown to be often numerically deficient and/or functionally aberrant.

Using Breg cells as markers of disease activity has so far proven to be difficult. In addition, total B cell depletion appears to be a highly efficacious therapy for a number of immune-mediated renal diseases, despite depletion of Breg cells as well. However, understanding the mechanisms through which B cell depletion therapy is effective in particular disease states has proven to be complex. The efficacy of such approaches is likely the result of a combination of reduced antibody secretion and antigen presentation by $\mathrm{B}$ cells as well as the expansion of Breg cells following repopulation(Figure 4). Future prospects for B cell targeting therapies may involve combinations of treatments to deplete pro-inflammatory subsets and expand regulatory subsets.

\section{Key points}

- B cells can promote disease through the production of antibodies, the release of proinflammatory cytokines or antigen presentation leading to $\mathrm{T}$ cell activation and polarisation

- Regulatory B (Breg) cell subsets can attenuate disease through the action of the immunomodulatory cytokine IL-10 and various other mechanisms 
- Imbalance in the numbers or function of pro-inflammatory and regulatory B cell subsets is found in various immune-mediated renal diseases and renal transplant cohorts

- Quantitative and qualitative assessment of B cell subsets may provide biomarkers for disease outcomes, predictors of disease relapse or instruct therapeutic strategies

- B cell depletion therapy has been successfully used for the treatment of various autoimmune diseases that affect the kidney as well as in renal transplantation

- As the currently available agents deplete regulatory and pro-inflammatory B cell subsets, new strategies such as the use of combination therapies and novel agents are required to enable more targeted therapy

Figure $1 \mathrm{~B}$ cell and Breg differentiation pathways Immature B cells from the bone marrow enter the spleen where they develop into mature B cells. Upon activation by antigen and with cognate $\mathrm{T}$ cell help, mature B cells either give rise to short-lived plasmablasts or enter the germinal centre (GC) reaction in which somatic hypermutation, affinity maturation and class-switch recombination occur. Somatic hypermutation introduces changes in the genes encoding regions of the immunoglobulin molecules involved in antigen recognition, the cells with increased specificity for antigen are then selected through affinity maturation. The isotype of the antibody produced can be changed through class-switch recombination. Certain B cells may then be selected into the memory B cell or long-lived plasma cell pools. Upon secondary antigen encounter, memory B cells can either give rise to antibody-secreting plasmablasts or to more memory B cells. IL-10-producing Breg cells have been shown to arise at multiple stages during B cell development and are enriched within $C D 24^{\text {hi }} C D 38^{\text {hi }}$ immature $\mathrm{B}$ cell and $\mathrm{CD} 24^{+} \mathrm{CD} 38^{\mathrm{hi}} \mathrm{CD} 27^{+}$memory B cells populations. In addition, immature or naïve mature $\mathrm{B}$ cells can give rise to $\mathrm{CD} 24 \mathrm{CD} 38^{\text {hi }} \mathrm{CD} 27^{+} \mathrm{IL}-10$-secreting plasmablasts. The precursors of Granzyme $\mathrm{B}^{+}$Breg cells remain to be identified.

Figure 2 B cell immune functions. a | B cells can contribute to immune responses through various mechanisms. They produce antibodies that bind to antigen and induce activation of the complement system or antibody-dependent cellular cytotoxicity. They can also function as antigen presenting cells to induce $\mathrm{T}$ cell activation and memory cell differentiation. Finally, B cells can secrete proinflammatory cytokines such as TNF- $\alpha$, IL-6, GM-CSF, and IFN- $\gamma$, which can activate myeloid lineage cells and polarize $\mathrm{T}$ cell responses to drive Th1 and Th17 responses. B cells can also regulate immune responses via the production of soluble mediators (IL-10, TGF- $\beta$, GzmB) and through surface expression of CD1d and PD-L1. These regulatory mechanisms inhibit T cells, monocytes, pDCs and promote Treg cell responses. BCR, B cell receptor; GzmB, Granzyme B; LT $\alpha 1 \beta 2$, lymphotoxin alpha1/beta2; TCR, T cell receptor.

Figure 3 Targets of B cell directed therapies. Current B cell directed therapies include the use of monoclonal antibodies against B cell surface markers, such as CD20, CD22, CD52 and CD19, which 
lead to depletion or attenuated activation of B cells. In addition, other monoclonal antibodies and fusion proteins are used to inhibit the binding of B cell growth factors to their cell surface receptors, resulting in diminished cell proliferation and activation. The molecular targets of these therapies include the BAFF and APRIL growth factors and the BCMA receptor. APRIL, a proliferationinducing ligand; BAFF, B cell activating factor; BCMA, B cell maturation antigen; mAb, monoclonal antibody.

Figure 4: Proposed mechanism of action of B cell depletion therapy on various immune circuits contributing to autoimmunity and transplant alloreactivity. Functional or numerical reduction in Breg activity promotes pro-inflammatory circuits with enhanced Th17, Th1 cell activation and pathogenic antibody production. Following B cell depletion, reduction in short lived plasma cells and some memory cells, reduces autoantibody production, pro-inflammatory cytokine production and antigen presentation to T cells. Following B cell reconstitution with greater proportions of immature cells, more regulatory circuits are re-established, with greater IL10 production and diminished Th17, Th1, and monocyte activation, allowing establishment of disease remission. 
Table 1 | Regulatory properties of human Breg cells

\begin{tabular}{|c|c|c|c|c|}
\hline $\begin{array}{l}\text { Breg cell subset or } \\
\text { variant }\end{array}$ & Phenotype & Functional effects & Mediators & Refs \\
\hline B10 cells & CD19+CD24hiCD27+ & $\begin{array}{l}\text { Suppress, monocyte effector function, including } \\
\text { TNF- } \alpha \text { production } \\
\text { B10 cell numbers do not correlate with disease } \\
\text { state in SLE, but are reduced in AAV }\end{array}$ & IL-10 & (57) \\
\hline Immature B cells & CD19+CD24hiCD38hi & $\begin{array}{l}\text { Suppress CD4+ Th1 cells (IFN- } \gamma \text { and TNF- } \alpha \\
\text { production) and Th17 cell (IL-17 production) } \\
\text { Suppress CD8+ T cell responses, induce Treg cells } \\
\text { and maintain iNKT cells } \\
\text { Role for PD-L1 signalling in inhibiting T cell } \\
\text { responses }\end{array}$ & $\begin{array}{l}\text { IL-10, CD80, CD86 } \\
\text { PD-L1 } \\
\text { Treg cell induction is contact } \\
\text { dependent }\end{array}$ & $\begin{array}{l}(56, \\
76)\end{array}$ \\
\hline Plasmablasts & $\begin{array}{l}\text { CD19+CD24hiCD38+CD27int } \\
\text { CD39+CD73+CD25+ }\end{array}$ & $\begin{array}{l}\text { Suppress dendritic cells and CD4+ T cells } \\
\text { Inhibit CD4+ and CD8+ T cell proliferation }\end{array}$ & IL-10;5-AMP, adenosine & $\begin{array}{l}(58, \\
177)\end{array}$ \\
\hline Br1 cells & CD19+CD25hiCD71hiCD73- & $\begin{array}{l}\text { Suppress antigen-specific proliferation of CD4+ T } \\
\text { cells }\end{array}$ & IL-10, IgG4 & $(83)$ \\
\hline \multirow[t]{3}{*}{ GzmB Breg cell } & & \multirow{3}{*}{$\begin{array}{l}\text { CD4+ T cell inhibition via enhanced } \mathrm{T} \text { cell } \\
\text { apoptosis and reduced proliferation }\end{array}$} & & \multirow[t]{3}{*}{ (94) } \\
\hline & $\begin{array}{l}\mathrm{CD} 19+\mathrm{CD} 138+\mathrm{CD} 38+\mathrm{CD} 25+\mathrm{CD} 27+\mathrm{GzmB} \\
+\end{array}$ & & $\begin{array}{l}\text { Contact-dependent } \\
\text { GzmB-mediated } \\
\text { No role for IL-10 or TGF } \beta\end{array}$ & \\
\hline & $\mathrm{CD} 19+\mathrm{CD} 38+\mathrm{CD} 25+\mathrm{CD} 1 \mathrm{~d}+\mathrm{CD} 10$ & & $\begin{array}{l}\text { IL-10, GzmB, indolemamine } \\
\text { dioxygenase }\end{array}$ & \\
\hline
\end{tabular}


Table 2 | Potential translational use of B cell subsets in renal disease*

\begin{tabular}{|c|c|c|c|c|}
\hline Disease & $\begin{array}{l}\text { Potential diagnostic } \\
\text { use }\end{array}$ & Finding & Translational Impact & Refs \\
\hline \multirow[t]{2}{*}{$\begin{array}{l}\text { Kidney } \\
\text { transplantation }\end{array}$} & $\begin{array}{l}\text { Breg cell } \\
\text { IL10:TNF- } \alpha \text { ratio }\end{array}$ & $\begin{array}{l}\text { Low cytokine ratio is a } \\
\text { marker of poorer outcome } \\
\text { with greater chronic immune } \\
\text { alloreactivity }\end{array}$ & \multirow{2}{*}{$\begin{array}{l}\text { Non-invasive means of } \\
\text { monitoring graft function. } \\
\text { Potential to augment or } \\
\text { optimise immunosuppression } \\
\text { in patients with low IL- } \\
\text { 10:TNF ratios or Breg } \\
\text { numbers }\end{array}$} & (101) \\
\hline & $\begin{array}{l}\mathrm{CD} 24^{\mathrm{hi}} \mathrm{CD} 38^{\mathrm{hi}} \text { Breg } \\
\text { cell number }\end{array}$ & $\begin{array}{l}\text { Lower Breg cell number is } \\
\text { associated with higher graft } \\
\text { rejection rates }\end{array}$ & & $82-84(97,99,100)$ \\
\hline \multirow[t]{3}{*}{$\begin{array}{l}\text { ANCA associated } \\
\text { Vasculitis }\end{array}$} & $\begin{array}{l}\text { Memory B cell } \\
\text { subsets }\end{array}$ & $\begin{array}{l}\text { Higher frequency of memory } \\
\text { B cells associated with } \\
\text { earlier relapse }\end{array}$ & \multirow[t]{3}{*}{$\begin{array}{l}\text { Potential to predict patients } \\
\text { at high risk of relapse }\end{array}$} & (178) \\
\hline & CD5+ B cells & $\begin{array}{l}\text { Lower numbers of CD5- } \\
\text { expressing B cells associated } \\
\text { with earlier relapse }\end{array}$ & & (116-118) \\
\hline & $\begin{array}{l}\text { Plasmablasts } \\
(\text { CD38hiCD27+) }\end{array}$ & $\begin{array}{l}\text { Higher plasmablast } \\
\text { percentage during remission } \\
\text { is predictive of relapse }\end{array}$ & & (179) \\
\hline \multirow[t]{2}{*}{ SLE } & $\begin{array}{l}\text { CD1d-expressing } \\
\text { immature B cells }\end{array}$ & $\begin{array}{l}\text { Restoration of CD1d } \\
\text { expression levels on } \\
\text { CD } 19 \text { CD } 38^{\text {hi }} \text { CD } 24^{\text {hi }} \text { cells is } \\
\text { associated with a clinical } \\
\text { response }\end{array}$ & $\begin{array}{l}\text { Potential to predict } \\
\text { satisfactory levels of } \\
\text { immunosuppression in } \\
\text { treated patients }\end{array}$ & $(75)$ \\
\hline & $\begin{array}{l}\text { Immature:memory } \\
\text { B cell ratio }\end{array}$ & $\begin{array}{l}\text { Higher ratio associated with } \\
\text { clinical response following } \\
\text { rituximab therapy }\end{array}$ & $\begin{array}{l}\text { Potential to define levels of } \\
\text { adequate treatment }\end{array}$ & (134) \\
\hline $\begin{array}{l}\text { Nephrotic } \\
\text { syndrome and/or } \\
\text { relapsing minimal } \\
\text { change disease }\end{array}$ & $\begin{array}{l}\text { Class switched } \\
\text { memory B cells }\end{array}$ & $\begin{array}{l}\text { Return of memory B cells } \\
\text { following rituximab therapy } \\
\text { is associated with disease } \\
\text { relapse }\end{array}$ & $\begin{array}{l}\text { Potential for monitoring and } \\
\text { timing of redosing of } \\
\text { rituximab treated patients }\end{array}$ & (147) \\
\hline IgG4RD & $\begin{array}{l}\text { Plasmablasts } \\
\text { (CD19lowCD38+C } \\
\text { D20-CD27+) }\end{array}$ & $\begin{array}{l}\text { Elevated levels associated } \\
\text { with disease activity }\end{array}$ & $\begin{array}{l}\text { Monitoring of therapeutic } \\
\text { response, potentially a better } \\
\text { marker than IgG4 levels }\end{array}$ & (141) \\
\hline
\end{tabular}

- Not confirmed in large prospective clinical trial samples. 
Table 3: Reported effects of immunosuppressive drugs on Breg cell populations

\begin{tabular}{|c|c|c|c|}
\hline Drug & Effect on Breg cells & Setting & ref \\
\hline Prednisolone & $\begin{array}{l}\text { Reduced numbers of } \\
\mathrm{CD} 19^{+} \mathrm{CD} 20^{+} \mathrm{CD} 24^{\mathrm{hi}} \mathrm{CD} 38^{\mathrm{hi}} \text { Breg cells in } \\
\text { patients on steroids compared to those off } \\
\text { steroids. } \\
\text { Increase in numbers following prospective } \\
\text { withdrawal of steroids }\end{array}$ & $\begin{array}{l}\text { Kidney } \\
\text { transplantation }\end{array}$ & $(95)$ \\
\hline Azathioprine & $\begin{array}{l}\text { Reduced numbers of } \\
\mathrm{CD} 19^{+} \mathrm{CD} 20^{+} \mathrm{CD} 24^{\mathrm{hi}} \mathrm{CD} 38^{\mathrm{hi}} \text { Breg cells } \\
\text { compared to patients not on azathioprine }\end{array}$ & $\begin{array}{l}\text { Kidney } \\
\text { transplantation }\end{array}$ & $(95)$ \\
\hline Calcineurin inhibitors & $\begin{array}{l}\text { Either no effect or reduced numbers of } \\
\mathrm{CD} 19^{+} \mathrm{CD} 20^{+} \mathrm{CD} 24^{\mathrm{hi}} \mathrm{CD} 38^{\mathrm{hi}} \text { cells compared } \\
\text { with healthy individuals }\end{array}$ & $\begin{array}{l}\text { Kidney } \\
\text { transplantation }\end{array}$ & $\begin{array}{l}(95,97, \\
98)\end{array}$ \\
\hline Sirolimus & $\begin{array}{l}\text { Reduced numbers of } \\
\mathrm{CD} 19^{+} \mathrm{CD} 20^{+} \mathrm{CD} 24^{\mathrm{hi}} \mathrm{CD} 38^{\mathrm{hi}} \text { cells, compared } \\
\text { with healthy individuals } \\
\text { Reduced numbers of naïve }\left(\mathrm{CD} 19^{+} \mathrm{IgD}{ }^{+} \mathrm{CD} 27^{-}\right) \\
\text {and greater numbers of memory } \\
\left(\mathrm{CD} 19^{+} \mathrm{IgD}{ }^{+} \mathrm{CD} 27^{+}\right) \text {B cells at one year } \\
\text { compared with CsA when used in combination } \\
\text { with thymoglobulin induction and with MMF } \\
\text { and steroid maintainence } \\
\text { Increased IL-10 and TGF- } \beta \text { production in B } \\
\text { cell-containing PBMCs, possibly regulating the } \\
\text { generation of Treg cells }\end{array}$ & $\begin{array}{l}\text { Kidney } \\
\text { transplantation }\end{array}$ & $\begin{array}{l}(97,106, \\
180,181)\end{array}$ \\
\hline Alemtuzumab & $\begin{array}{l}\text { Increased levels of CD } 19^{+} \mathrm{CD} 20^{+} \mathrm{CD} 24^{\mathrm{hi}} \mathrm{CD} 38^{\mathrm{hi}} \\
\text { Breg cells comared with basiliximab treated } \\
\text { subjects } \\
\text { Transient increase (at } 6 \text { months) in Breg cell } \\
\text { numbers and persistence of naïve B cells, } \\
\text { irrespective of sirolimus of tacrolimus } \\
\text { maintenance }\end{array}$ & $\begin{array}{l}\text { Kidney } \\
\text { transplantation }\end{array}$ & $\begin{array}{l}(102, \\
182)\end{array}$ \\
\hline Abatacept & $\begin{array}{l}\text { No change in } \mathrm{CD} 19^{+} \mathrm{CD} 20^{+} \mathrm{CD} 24^{\mathrm{hi}} \mathrm{CD} 38^{\mathrm{hi}} \text { Breg } \\
\text { cells after } 6 \text { months of therapy }\end{array}$ & RA & $(89)$ \\
\hline Rituximab & Repopulation of B cells following rituximab is & SLE, AAV & $(112$, \\
\hline
\end{tabular}




\begin{tabular}{|l|l|l|l|}
\hline & $\begin{array}{l}\text { associated with a relative increase in immature } \\
\text { B cells compared with memory B cells }\end{array}$ & $134)$ \\
\hline
\end{tabular}

CsA, cyclosporine A; HC, healthy control; MMF, mycophenolate mofetil; PBMC, peripherial blood mononuclear cells; RA, rheumatoid arthritis; SLE, sytemic lupus erythematosus.

\section{Acknowledgments}

A.D.S. is supported by Kidney Research UK.

\section{Author contributions}

All authors contributed to researching data for the article, discussing the article's content, writing the article and reviewing and editing the manuscript before submission.

\section{Competing interests}

The authors declare no competing interests.

\section{Publisher's note}

Springer Nature remains neutral with regard to jurisdictional claims in published maps and institutional affiliations.

\section{Reviewer information}

TBC

\section{Glossary terms}

Operational tolerance: long-term allograft acceptance without the requirement for continuous immunosuppression.

Germinal centre reaction: process through which high-affinity, class-switched plasma cells and memory B cells are generated

type 1 response: producing Th1 cytokines, such as IFN-g and IL12

type 2 response producing Th2 cytokines, such as IL4

iNKT: CD1d-resticted lipid-reactive T cell population that express a semi-invariant $\alpha \beta \mathrm{T}$ cell receptor Induction therapy: Initial immunosuppressive therapy at time of transplantation or initial treatment of autoimmune disease

Maintenance therapy: Continuous immunosuppression to maintain stable graft function or remission in autoimmunity,

Cryoglobulinaemia: Syndrome of circulating cryoglobulins, immunoglobulins that precipitate at temperatures below $37^{\circ} \mathrm{C}$, leading to skin, kidney and neurological disease

Nephrotic syndrome: A triad of oedema, proteinuria of more than 3.5g/day and hypoalbuminaemia. Often with marked hypercholesterolaemia. 
Membranous glomerulonephritis: Maybe primary (Idiopathic ) or secondary to other diseases, such as SLE; A glomerular disease with subepithelial immune complexes, causing nephrotic syndrome, frequently associated with antibodies to phospholipase A2 receptor or thrombospondin type 1 domain-containing 7A

Minimal change disease: a common cause of nephrotic syndrome in children and adults, with minimal histological abnormalities on light microscopy, but podocyte effacement on electron microscopy.

1. Guillevin L, Pagnoux C, Karras A, Khouatra C, Aumaitre O, Cohen P, et al. Rituximab versus azathioprine for maintenance in ANCA-associated vasculitis. N Engl J Med. 2014;371(19):1771-80.

2. Jones RB, Tervaert JW, Hauser T, Luqmani R, Morgan MD, Peh CA, et al. Rituximab versus cyclophosphamide in ANCA-associated renal vasculitis. N Engl J Med. 2010;363(3):211-20.

3. Stone JH, Merkel PA, Spiera R, Seo P, Langford CA, Hoffman GS, et al. Rituximab versus cyclophosphamide for ANCA-associated vasculitis. N Engl J Med. 2010;363(3):221-32.

4. De Vita S, Quartuccio L, Isola M, Mazzaro C, Scaini P, Lenzi M, et al. A randomized controlled trial of rituximab for the treatment of severe cryoglobulinemic vasculitis. Arthritis Rheum. 2012;64(3):843-53.

5. Fornoni A, Sageshima J, Wei C, Merscher-Gomez S, Aguillon-Prada R, Jauregui AN, et al. Rituximab targets podocytes in recurrent focal segmental glomerulosclerosis. Sci Transl Med. 2011;3(85):85ra46.

6. Liu LL, Qin Y, Cai JF, Wang HY, Tao JL, Li H, et al. Th17/Treg imbalance in adult patients with minimal change nephrotic syndrome. Clin Immunol. 2011;139(3):314-20.

7. Sims GP, Ettinger R, Shirota Y, Yarboro CH, Illei GG, Lipsky PE. Identification and characterization of circulating human transitional B cells. Blood. 2005;105(11):4390-8.

8. Ahmed R, Gray D. Immunological memory and protective immunity: Understanding their relation. Science. 1996;272(5258):54-60.

9. Mesin L, Ersching J, Victora GD. Germinal Center B Cell Dynamics. Immunity. 2016;45(3):471-

82.

10. Plotkin SA. Correlates of protection induced by vaccination. Clin Vaccine Immunol. 2010;17(7):1055-65.

11. Epstein MM, Di Rosa F, Jankovic D, Sher A, Matzinger P. Successful T cell priming in B celldeficient mice. J Exp Med. 1995;182(4):915-22.

12. Phillips JA, Romball CG, Hobbs MV, Ernst DN, Shultz L, Weigle WO. CD4+ T cell activation and tolerance induction in B cell knockout mice. J Exp Med. 1996;183(4):1339-44.

13. Topham DJ, Tripp RA, Hamilton-Easton AM, Sarawar SR, Doherty PC. Quantitative analysis of the influenza virus-specific CD4+ T cell memory in the absence of B cells and Ig. J Immunol. 1996;157(7):2947-52.

14. Angeli V, Ginhoux F, Llodra J, Quemeneur L, Frenette PS, Skobe M, et al. B cell-driven lymphangiogenesis in inflamed lymph nodes enhances dendritic cell mobilization. Immunity. 2006;24(2):203-15.

15. Homann D, Tishon A, Berger DP, Weigle WO, von Herrath MG, Oldstone MB. Evidence for an underlying CD4 helper and CD8 T-cell defect in B-cell-deficient mice: failure to clear persistent virus infection after adoptive immunotherapy with virus-specific memory cells from muMT/muMT mice. J Virol. 1998;72(11):9208-16.

16. Bouaziz JD, Yanaba K, Venturi GM, Wang Y, Tisch RM, Poe JC, et al. Therapeutic B cell depletion impairs adaptive and autoreactive CD4+ T cell activation in mice. Proc Natl Acad Sci U S A. 2007;104(52):20878-83. 
17. Chan OT, Hannum LG, Haberman AM, Madaio MP, Shlomchik MJ. A novel mouse with B cells but lacking serum antibody reveals an antibody-independent role for $B$ cells in murine lupus. J Exp Med. 1999;189(10):1639-48.

18. Chatzidionysiou K, Lie E, Nasonov E, Lukina G, Hetland ML, Tarp U, et al. Highest clinical effectiveness of rituximab in autoantibody-positive patients with rheumatoid arthritis and in those for whom no more than one previous TNF antagonist has failed: pooled data from 10 European registries. Ann Rheum Dis. 2011;70(9):1575-80.

19. Tomana M, Novak J, Julian BA, Matousovic K, Konecny K, Mestecky J. Circulating immune complexes in IgA nephropathy consist of IgA1 with galactose-deficient hinge region and antiglycan antibodies. J Clin Invest. 1999;104(1):73-81.

20. van der Woude FJ, Rasmussen N, Lobatto S, Wiik A, Permin H, van Es LA, et al.

Autoantibodies against neutrophils and monocytes: tool for diagnosis and marker of disease activity in Wegener's granulomatosis. Lancet. 1985;1(8426):425-9.

21. Wilson CB, Dixon FJ. Anti-glomerular basement membrane antibody-induced glomerulonephritis. Kidney Int. 1973;3(2):74-89.

22. Boh EE. Neonatal lupus erythematosus. Clin Dermatol. 2004;22(2):125-8.

23. Schlieben DJ, Korbet SM, Kimura RE, Schwartz MM, Lewis EJ. Pulmonary-renal syndrome in a newborn with placental transmission of ANCAs. Am J Kidney Dis. 2005;45(4):758-61.

24. Colvin RB, Smith RN. Antibody-mediated organ-allograft rejection. Nature Reviews Immunology. 2005;5(10):807-17.

25. Loupy A, Hill GS, Jordan SC. The impact of donor-specific anti-HLA antibodies on late kidney allograft failure. Nature Reviews Nephrology. 2012;8(6):348-57.

26. Smith RN, Colvin RB. Chronic alloantibody mediated rejection. Seminars in Immunology. 2012;24(2):115-21.

27. Porcheray F, DeVito J, Yeap BY, Xue L, Dargon I, Paine R, et al. Chronic Humoral Rejection of Human Kidney Allografts Associates With Broad Autoantibody Responses. Transplantation. 2010;89(10):1239-46.

28. Kissmeye F, Olsen S, Petersen VP, Fjeldborg O. Hyperacute Rejection of Kidney Allografts Associated with Pre-Existing Humoral Antibodies against Donor Cells. Lancet. 1966;2(7465):662-+. 29. Lefaucheur C, Viglietti D, Bentlejewski C, van Huyen JPD, Vernerey D, Aubert O, et al. IgG Donor-Specific Anti-Human HLA Antibody Subclasses and Kidney Allograft Antibody-Mediated Injury. Journal of the American Society of Nephrology. 2016;27(1):293-304.

30. Vidarsson G, Dekkers G, Rispens T. IgG subclasses and allotypes: from structure to effector functions. Front Immunol. 2014;5:520.

31. Wunderlich C, Oliviera I, Figueiredo CP, Rech J, Schett G. Effects of DMARDs on citrullinated peptide autoantibody levels in RA patients-A longitudinal analysis. Semin Arthritis Rheum.

2017;46(6):709-14.

32. Huang $\mathrm{H}$, Benoist $\mathrm{C}$, Mathis $\mathrm{D}$. Rituximab specifically depletes short-lived autoreactive plasma cells in a mouse model of inflammatory arthritis. Proc Natl Acad Sci U S A.

2010;107(10):4658-63.

33. Rodriguez-Pinto D. B cells as antigen presenting cells. Cellular Immunology. 2005;238(2):6775.

34. Liossis SN, Sfikakis PP. Rituximab-induced B cell depletion in autoimmune diseases: potential effects on T cells. Clin Immunol. 2008;127(3):280-5.

35. Noorchashm H, Reed AJ, Rostami SY, Mozaffari R, Zekavat G, Koeberlein B, et al. B cellmediated antigen presentation is required for the pathogenesis of acute cardiac allograft rejection. Journal of Immunology. 2006;177(11):7715-22.

36. Zeng $\mathrm{Q}, \mathrm{Ng} \mathrm{YH}$, Singh $\mathrm{T}$, Jiang $\mathrm{K}$, Sheriff KA, Ippolito R, et al. B cells mediate chronic allograft rejection independently of antibody production. Journal of Clinical Investigation. 2014;124(3):10526. 
37. Shiu KY, McLaughlin L, Rebollo-Mesa I, Zhao JY, Burton H, Douthwaite H, et al. Graft dysfunction in chronic antibody-mediated rejection correlates with B-cell-dependent indirect antidonor alloresponses and autocrine regulation of interferon-gamma production by Th1 cells. Kidney International. 2017;91(2):477-92.

38. Yan J, Mamula MJ. B and T cell tolerance and autoimmunity in autoantibody transgenic mice. Int Immunol. 2002;14(8):963-71.

39. Shen P, Fillatreau S. Antibody-independent functions of B cells: a focus on cytokines. Nature Reviews Immunology. 2015;15(7):441-51.

40. Harris DP, Haynes L, Sayles PC, Duso DK, Eaton SM, Lepak NM, et al. Reciprocal regulation of polarized cytokine production by effector B and T cells. Nat Immunol. 2000;1(6):475-82.

41. Wojciechowski W, Harris DP, Sprague F, Mousseau B, Makris M, Kusser K, et al. CytokineProducing Effector B Cells Regulate Type 2 Immunity to H. polygyrus. Immunity. 2009;30(3):421-33.

42. Barr TA, Shen P, Brown S, Lampropoulou V, Roch T, Lawrie S, et al. B cell depletion therapy ameliorates autoimmune disease through ablation of IL-6-producing B cells. Journal of Experimental Medicine. 2012;209(5):1001-10.

43. Li R, Rezk A, Miyazaki Y, Hilgenberg E, Touil H, Shen P, et al. Proinflammatory GM-CSFproducing $B$ cells in multiple sclerosis and B cell depletion therapy. Sci Transl Med. 2015;7(310):310ra166.

44. Sieber J, Daridon C, Fleischer SJ, Fleischer V, Hiepe F, Alexander T, et al. Active systemic lupus erythematosus is associated with a reduced cytokine production by B cells in response to TLR9 stimulation. Arthritis Res Ther. 2014;16(6):477.

45. Noronha IL, Kruger C, Andrassy K, Ritz E, Waldherr R. Insitu Production of Tnf-Alpha, Il-1-Beta and II-2r in Anca-Positive Glomerulonephritis. Kidney International. 1993;43(3):682-92.

46. Haas C, Ryffel B, LeHir M. IFN-gamma is essential for the development of autoimmune glomerulonephritis in MRL/Ipr mice. Journal of Immunology. 1997;158(11):5484-91.

47. Kerjaschki D, Regele HM, Moosberger I, Nagy-Bojarski K, Watschinger B, Soleiman A, et al. Lymphatic neoangiogenesis in human kidney transplants is associated with immunologically active lymphocytic infiltrates. J Am Soc Nephrol. 2004;15(3):603-12.

48. Sarwal M, Chua MS, Kambham N, Hsieh SC, Satterwhite T, Masek M, et al. Molecular heterogeneity in acute renal allograft rejection identified by DNA microarray profiling. $N$ Engl J Med. 2003;349(2):125-38.

49. Tsai EW, Rianthavorn P, Gjertson DW, Wallace WD, Reed EF, Ettenger RB. CD20+ lymphocytes in renal allografts are associated with poor graft survival in pediatric patients. Transplantation. 2006;82(12):1769-73.

50. Heller F, Lindenmeyer MT, Cohen CD, Brandt U, Draganovici D, Fischereder M, et al. The contribution of $B$ cells to renal interstitial inflammation. Am J Pathol. 2007;170(2):457-68.

51. Hruskova Z, Honsova E, Berden AE, Rychlik I, Lanska V, Zabka J, et al. Repeat protocol renal biopsy in ANCA-associated renal vasculitis. Nephrol Dial Transplant. 2014;29(9):1728-32.

52. Mauri C, Bosma A. Immune regulatory function of B cells. Annu Rev Immunol. 2012;30:221-

41.

53. Menon M, Blair PA, Isenberg DA, Mauri C. A Regulatory Feedback between Plasmacytoid Dendritic Cells and Regulatory B Cells Is Aberrant in Systemic Lupus Erythematosus. Immunity. 2016;44(3):683-97.

54. Rosser EC, Oleinika K, Tonon S, Doyle R, Bosma A, Carter NA, et al. Regulatory B cells are induced by gut microbiota-driven interleukin-1beta and interleukin- 6 production. Nat Med. 2014;20(11):1334-9.

55. Yoshizaki A, Miyagaki T, DiLillo DJ, Matsushita T, Horikawa M, Kountikov El, et al. Regulatory B cells control T-cell autoimmunity through IL-21-dependent cognate interactions. Nature. 2012;491(7423):264-8. 
56. Blair PA, Norena LY, Flores-Borja F, Rawlings DJ, Isenberg DA, Ehrenstein MR, et al. CD19(+)CD24(hi)CD38(hi) B cells exhibit regulatory capacity in healthy individuals but are functionally impaired in systemic Lupus Erythematosus patients. Immunity. 2010;32(1):129-40.

57. Iwata Y, Matsushita T, Horikawa M, Dilillo DJ, Yanaba K, Venturi GM, et al. Characterization of a rare IL-10-competent B-cell subset in humans that parallels mouse regulatory B10 cells. Blood. 2011;117(2):530-41.

58. Matsumoto M, Baba A, Yokota T, Nishikawa H, Ohkawa Y, Kayama H, et al. Interleukin-10producing plasmablasts exert regulatory function in autoimmune inflammation. Immunity. 2014;41(6):1040-51.

59. Fillatreau S, Sweenie CH, McGeachy MJ, Gray D, Anderton SM. B cells regulate autoimmunity by provision of IL-10. Nat Immunol. 2002;3(10):944-50.

60. Burkett PR, Meyer zu Horste G, Kuchroo VK. Pouring fuel on the fire: Th17 cells, the environment, and autoimmunity. J Clin Invest. 2015;125(6):2211-9.

61. Matsumoto M, Fujii Y, Baba A, Hikida M, Kurosaki T, Baba Y. The calcium sensors STIM1 and STIM2 control B cell regulatory function through interleukin-10 production. Immunity. 2011;34(5):703-14.

62. Mauri C, Gray D, Mushtaq N, Londei M. Prevention of arthritis by interleukin 10-producing B cells. J Exp Med. 2003;197(4):489-501.

63. Mizoguchi A, Mizoguchi E, Takedatsu H, Blumberg RS, Bhan AK. Chronic intestinal inflammatory condition generates IL-10-producing regulatory B cell subset characterized by CD1d upregulation. Immunity. 2002;16(2):219-30.

64. Blair PA, Chavez-Rueda KA, Evans JG, Shlomchik MJ, Eddaoudi A, Isenberg DA, et al. Selective targeting of $B$ cells with agonistic anti-CD40 is an efficacious strategy for the generation of induced regulatory T2-like B cells and for the suppression of lupus in MRL/Ipr mice. J Immunol.

2009;182(6):3492-502.

65. Liu BS, Cao Y, Huizinga TW, Hafler DA, Toes RE. TLR-mediated STAT3 and ERK activation controls IL-10 secretion by human B cells. Eur J Immunol. 2014;44(7):2121-9.

66. Lampropoulou V, Hoehlig K, Roch T, Neves P, Calderon Gomez E, Sweenie CH, et al. TLRactivated B cells suppress T cell-mediated autoimmunity. J Immunol. 2008;180(7):4763-73.

67. Tian J, Zekzer D, Hanssen L, Lu Y, Olcott A, Kaufman DL. Lipopolysaccharide-activated B cells down-regulate Th1 immunity and prevent autoimmune diabetes in nonobese diabetic mice. J Immunol. 2001;167(2):1081-9.

68. Carter NA, Vasconcellos R, Rosser EC, Tulone C, Munoz-Suano A, Kamanaka M, et al. Mice lacking endogenous IL-10-producing regulatory $B$ cells develop exacerbated disease and present with an increased frequency of Th1/Th17 but a decrease in regulatory T cells. J Immunol.

2011;186(10):5569-79.

69. Carter NA, Rosser EC, Mauri C. Interleukin-10 produced by B cells is crucial for the suppression of Th17/Th1 responses, induction of T regulatory type 1 cells and reduction of collageninduced arthritis. Arthritis Res Ther. 2012;14(1):R32.

70. Sun JB, Flach CF, Czerkinsky C, Holmgren J. B lymphocytes promote expansion of regulatory T cells in oral tolerance: powerful induction by antigen coupled to cholera toxin B subunit. J Immunol. 2008;181(12):8278-87.

71. Tadmor T, Zhang Y, Cho HM, Podack ER, Rosenblatt JD. The absence of B lymphocytes reduces the number and function of T-regulatory cells and enhances the anti-tumor response in a murine tumor model. Cancer Immunol Immunother. 2011;60(5):609-19.

72. Shen P, Roch T, Lampropoulou V, O'Connor RA, Stervbo U, Hilgenberg E, et al. IL-35producing $B$ cells are critical regulators of immunity during autoimmune and infectious diseases. Nature. 2014;507(7492):366-70.

73. Wang RX, Yu CR, Dambuza IM, Mahdi RM, Dolinska MB, Sergeev YV, et al. Interleukin-35 induces regulatory B cells that suppress autoimmune disease. Nat Med. 2014;20(6):633-41. 
74. Mauri C, Menon M. Human regulatory B cells in health and disease: therapeutic potential. J Clin Invest. 2017;127(3):772-9.

75. Bosma A, Abdel-Gadir A, Isenberg DA, Jury EC, Mauri C. Lipid-antigen presentation by $\mathrm{CD} 1 \mathrm{~d}(+) \mathrm{B}$ cells is essential for the maintenance of invariant natural killer T cells. Immunity. 2012;36(3):477-90.

76. Flores-Borja F, Bosma A, Ng D, Reddy V, Ehrenstein MR, Isenberg DA, et al. CD19+CD24hiCD38hi B cells maintain regulatory T cells while limiting TH1 and TH17 differentiation. Sci Transl Med. 2013;5(173):173ra23.

77. Knippenberg S, Peelen E, Smolders J, Thewissen M, Menheere P, Cohen Tervaert JW, et al. Reduction in IL-10 producing B cells (Breg) in multiple sclerosis is accompanied by a reduced naive/memory Breg ratio during a relapse but not in remission. J Neuroimmunol. 2011;239(1-2):806.

78. Hayashi M, Yanaba K, Umezawa Y, Yoshihara Y, Kikuchi S, Ishiuji Y, et al. IL-10-producing regulatory B cells are decreased in patients with psoriasis. J Dermatol Sci. 2016;81(2):93-100.

79. Barsotti NS, Almeida RR, Costa PR, Barros MT, Kalil J, Kokron CM. IL-10-Producing Regulatory B Cells Are Decreased in Patients with Common Variable Immunodeficiency. PLoS One. 2016;11(3):e0151761.

80. Nouel A, Pochard P, Simon Q, Segalen I, Le Meur Y, Pers JO, et al. B-Cells induce regulatory T cells through TGF-beta/IDO production in A CTLA-4 dependent manner. J Autoimmun. 2015;59:5360.

81. Khan AR, Hams E, Floudas A, Sparwasser T, Weaver CT, Fallon PG. PD-L1hi B cells are critical regulators of humoral immunity. Nat Commun. 2015;6:5997.

82. Kessel A, Haj T, Peri R, Snir A, Melamed D, Sabo E, et al. Human CD19(+)CD25(high) B regulatory cells suppress proliferation of CD4(+) T cells and enhance Foxp3 and CTLA-4 expression in T-regulatory cells. Autoimmun Rev. 2012;11(9):670-7.

83. van de Veen W, Stanic B, Yaman G, Wawrzyniak M, Sollner S, Akdis DG, et al. IgG4 production is confined to human IL-10-producing regulatory $B$ cells that suppress antigen-specific immune responses. J Allergy Clin Immunol. 2013;131(4):1204-12.

84. Lindner S, Dahlke K, Sontheimer K, Hagn M, Kaltenmeier C, Barth TF, et al. Interleukin 21induced granzyme B-expressing B cells infiltrate tumors and regulate T cells. Cancer Res. 2013;73(8):2468-79.

85. Amu S, Saunders SP, Kronenberg M, Mangan NE, Atzberger A, Fallon PG. Regulatory B cells prevent and reverse allergic airway inflammation via FoxP3-positive T regulatory cells in a murine model. J Allergy Clin Immunol. 2010;125(5):1114-24 e8.

86. Novak J, Lehuen A. Mechanism of regulation of autoimmunity by iNKT cells. Cytokine. 2011;53(3):263-70.

87. Oleinika. CD1d-dependent immune suppression mediated by regulatory B cells through modulations of iNKT cells. Nature Communications. 2018;9(684).

88. Vivarelli M, Massella L, Ruggiero B, Emma F. Minimal Change Disease. Clin J Am Soc Nephrol. 2017;12(2):332-45.

89. Picchianti Diamanti A, Rosado MM, Scarsella M, Germano V, Giorda E, Cascioli S, et al. Abatacept (cytotoxic T lymphocyte antigen 4-immunoglobulin) improves B cell function and regulatory $T$ cell inhibitory capacity in rheumatoid arthritis patients non-responding to anti-tumour necrosis factor-alpha agents. Clin Exp Immunol. 2014;177(3):630-40.

90. Kim KW, Chung BH, Jeon EJ, Kim BM, Choi BS, Park CW, et al. B cell-associated immune profiles in patients with end-stage renal disease (ESRD). Exp Mol Med. 2012;44(8):465-72.

91. Newell KA, Asare A, Kirk AD, Gisler TD, Bourcier K, Suthanthiran M, et al. Identification of a B cell signature associated with renal transplant tolerance in humans. J Clin Invest. 2010;120(6):183647. 
92. Sagoo P, Perucha E, Sawitzki B, Tomiuk S, Stephens DA, Miqueu P, et al. Development of a cross-platform biomarker signature to detect renal transplant tolerance in humans. J Clin Invest. 2010;120(6):1848-61.

93. Chesneau M, Michel L, Degauque N, Brouard S. Regulatory B cells and tolerance in transplantation: from animal models to human. Front Immunol. 2013;4:497.

94. Chesneau M, Michel L, Dugast E, Chenouard A, Baron D, Pallier A, et al. Tolerant Kidney Transplant Patients Produce B Cells with Regulatory Properties. J Am Soc Nephrol. 2015;26(10):2588-

98.

95. Rebollo-Mesa I, Nova-Lamperti E, Mobillo P, Runglall M, Christakoudi S, Norris S, et al. Biomarkers of Tolerance in Kidney Transplantation: Are We Predicting Tolerance or Response to Immunosuppressive Treatment? Am J Transplant. 2016;16(12):3443-57.

96. Lozano JJ, Pallier A, Martinez-Llordella M, Danger R, Lopez M, Giral M, et al. Comparison of transcriptional and blood cell-phenotypic markers between operationally tolerant liver and kidney recipients. Am J Transplant. 2011;11(9):1916-26.

97. Latorre I, Esteve-Sole A, Redondo D, Giest S, Argilaguet J, Alvarez S, et al. Calcineurin and mTOR inhibitors have opposing effects on regulatory $T$ cells while reducing regulatory $B$ cell populations in kidney transplant recipients. Transpl Immunol. 2016;35:1-6.

98. Heinemann K, Wilde B, Hoerning A, Tebbe B, Kribben A, Witzke O, et al. Decreased IL-10(+) regulatory B cells (Bregs) in lupus nephritis patients. Scand J Rheumatol. 2016;45(4):312-6.

99. Shabir S, Girdlestone J, Briggs D, Kaul B, Smith H, Daga S, et al. Transitional B lymphocytes are associated with protection from kidney allograft rejection: a prospective study. Am J Transplant. 2015;15(5):1384-91.

100. Schlosser HA, Thelen M, Dieplinger G, von Bergwelt-Baildon A, Garcia-Marquez M, Reuter S, et al. Prospective Analyses of Circulating B Cell Subsets in ABO-Compatible and ABO-Incompatible Kidney Transplant Recipients. Am J Transplant. 2017;17(2):542-50.

101. Cherukuri A, Rothstein DM, Clark B, Carter CR, Davison A, Hernandez-Fuentes M, et al. Immunologic human renal allograft injury associates with an altered IL-10/TNF-alpha expression ratio in regulatory B cells. J Am Soc Nephrol. 2014;25(7):1575-85.

102. Cherukuri A, Salama AD, Carter C, Smalle N, McCurtin R, Hewitt EW, et al. An analysis of lymphocyte phenotype after steroid avoidance with either alemtuzumab or basiliximab induction in renal transplantation. Am J Transplant. 2012;12(4):919-31.

103. Clatworthy MR, Watson CJ, Plotnek G, Bardsley V, Chaudhry AN, Bradley JA, et al. B-celldepleting induction therapy and acute cellular rejection. N Engl J Med. 2009;360(25):2683-5.

104. Barnett AN, Hadjianastassiou VG, Mamode N. Rituximab in renal transplantation. Transpl Int. 2013;26(6):563-75.

105. Tyden G, Genberg H, Tollemar J, Ekberg H, Persson NH, Tufveson G, et al. A randomized, doubleblind, placebo-controlled, study of single-dose rituximab as induction in renal transplantation. Transplantation. 2009;87(9):1325-9.

106. Tebbe B, Wilde B, Ye Z, Wang J, Wang X, Jian F, et al. Renal Transplant Recipients Treated with Calcineurin-Inhibitors Lack Circulating Immature Transitional CD19+CD24hiCD38hi Regulatory B-Lymphocytes. PLoS One. 2016;11(4):e0153170.

107. McGregor JG, Hogan SL, Kotzen ES, Poulton CJ, Hu Y, Negrete-Lopez R, et al. Rituximab as an immunosuppressant in antineutrophil cytoplasmic antibody-associated vasculitis. Nephrol Dial Transplant. 2015;30 Suppl 1:i123-31.

108. Steinmetz OM, Velden J, Kneissler U, Marx M, Klein A, Helmchen U, et al. Analysis and classification of B-cell infiltrates in lupus and ANCA-associated nephritis. Kidney Int. 2008;74(4):44857.

109. Ferraro AJ, Smith SW, Neil D, Savage CO. Relapsed Wegener's granulomatosis after rituximab therapy--B cells are present in new pathological lesions despite persistent 'depletion' of peripheral blood. Nephrol Dial Transplant. 2008;23(9):3030-2. 
110. Eriksson P, Sandell C, Backteman K, Ernerudh J. B cell abnormalities in Wegener's granulomatosis and microscopic polyangiitis: role of CD25+-expressing B cells. J Rheumatol. 2010;37(10):2086-95.

111. Lepse N, Abdulahad WH, Rutgers A, Kallenberg CG, Stegeman CA, Heeringa P. Altered B cell balance, but unaffected $B$ cell capacity to limit monocyte activation in anti-neutrophil cytoplasmic antibody-associated vasculitis in remission. Rheumatology (Oxford). 2014;53(9):1683-92.

112. Todd SK, Pepper RJ, Draibe J, Tanna A, Pusey CD, Mauri C, et al. Regulatory B cells are numerically but not functionally deficient in anti-neutrophil cytoplasm antibody-associated vasculitis. Rheumatology (Oxford). 2014;53(9):1693-703.

113. Wilde B, Thewissen M, Damoiseaux J, Knippenberg S, Hilhorst M, van Paassen P, et al. Regulatory B cells in ANCA-associated vasculitis. Ann Rheum Dis. 2013;72(8):1416-9.

114. Wilde B, Witzke O, Cohen Tervaert JW. Rituximab and B-cell return in ANCA-associated vasculitis. Am J Kidney Dis. 2014;63(6):1066.

115. Gary-Gouy H, Harriague J, Bismuth G, Platzer C, Schmitt C, Dalloul AH. Human CD5 promotes B-cell survival through stimulation of autocrine IL-10 production. Blood. 2002;100(13):4537-43.

116. Bunch DO, McGregor JG, Khandoobhai NB, Aybar LT, Burkart ME, Hu Y, et al. Decreased CD5(+) B cells in active ANCA vasculitis and relapse after rituximab. Clin J Am Soc Nephrol. 2013;8(3):382-91.

117. Bunch DO, Mendoza CE, Aybar LT, Kotzen ES, Colby KR, Hu Y, et al. Gleaning relapse risk from $B$ cell phenotype: decreased $C D 5+B$ cells portend a shorter time to relapse after $B$ cell depletion in patients with ANCA-associated vasculitis. Ann Rheum Dis. 2015;74(9):1784-6.

118. Unizony S, Lim N, Phippard DJ, Carey VJ, Miloslavsky EM, Tchao NK, et al. Peripheral CD5+ B cells in antineutrophil cytoplasmic antibody-associated vasculitis. Arthritis Rheumatol.

2015;67(2):535-44.

119. Rahman A, Isenberg DA. Systemic lupus erythematosus. N Engl J Med. 2008;358(9):929-39.

120. Karrar S, Cunninghame Graham DS. Abnormal B Cell Development in Systemic Lupus

Erythematosus: What the Genetics Tell Us. Arthritis Rheumatol. 2018;70(4):496-507.

121. Merrill JT, Neuwelt CM, Wallace DJ, Shanahan JC, Latinis KM, Oates JC, et al. Efficacy and safety of rituximab in moderately-to-severely active systemic lupus erythematosus: the randomized, double-blind, phase II/III systemic lupus erythematosus evaluation of rituximab trial. Arthritis Rheum. 2010;62(1):222-33.

122. Rovin BH, Furie R, Latinis K, Looney RJ, Fervenza FC, Sanchez-Guerrero J, et al. Efficacy and safety of rituximab in patients with active proliferative lupus nephritis: the Lupus Nephritis Assessment with Rituximab study. Arthritis Rheum. 2012;64(4):1215-26.

123. Reddy V, Jayne D, Close D, Isenberg D. B-cell depletion in SLE: clinical and trial experience with rituximab and ocrelizumab and implications for study design. Arthritis Res Ther. 2013;15 Suppl 1:S2.

124. Manzi S, Sanchez-Guerrero J, Merrill JT, Furie R, Gladman D, Navarra SV, et al. Effects of belimumab, a B lymphocyte stimulator-specific inhibitor, on disease activity across multiple organ domains in patients with systemic lupus erythematosus: combined results from two phase III trials. Ann Rheum Dis. 2012;71(11):1833-8.

125. Mota P, Reddy V, Isenberg D. Improving B-cell depletion in systemic lupus erythematosus and rheumatoid arthritis. Expert Rev Clin Immunol. 2017;13(7):667-76.

126. Sim JH, Kim HR, Chang SH, Kim IJ, Lipsky PE, Lee J. Autoregulatory function of interleukin-10producing pre-naive $B$ cells is defective in systemic lupus erythematosus. Arthritis Res Ther.

2015;17:190.

127. Wang S, Wang J, Kumar V, Karnell JL, Naiman B, Gross PS, et al. IL-21 drives expansion and plasma cell differentiation of autoreactive CD11c(hi)T-bet(+) B cells in SLE. Nat Commun.

2018;9(1):1758. 
128. Kojo S, Adachi Y, Keino H, Taniguchi M, Sumida T. Dysfunction of T cell receptor AV24AJ18+, BV11+ double-negative regulatory natural killer T cells in autoimmune diseases. Arthritis Rheum. 2001;44(5):1127-38.

129. Green MR, Kennell AS, Larche MJ, Seifert MH, Isenberg DA, Salaman MR. Natural killer T cells in families of patients with systemic lupus erythematosus: their possible role in regulation of IGG production. Arthritis Rheum. 2007;56(1):303-10.

130. Cho YN, Kee SJ, Lee SJ, Seo SR, Kim TJ, Lee SS, et al. Numerical and functional deficiencies of natural killer T cells in systemic lupus erythematosus: their deficiency related to disease activity. Rheumatology (Oxford). 2011;50(6):1054-63.

131. Jego G, Palucka AK, Blanck JP, Chalouni C, Pascual V, Banchereau J. Plasmacytoid dendritic cells induce plasma cell differentiation through type I interferon and interleukin 6. Immunity. 2003;19(2):225-34.

132. Poeck H, Wagner M, Battiany J, Rothenfusser S, Wellisch D, Hornung V, et al. Plasmacytoid dendritic cells, antigen, and CpG-C license human B cells for plasma cell differentiation and immunoglobulin production in the absence of T-cell help. Blood. 2004;103(8):3058-64.

133. Fleischer V, Sieber J, Fleischer SJ, Shock A, Heine G, Daridon C, et al. Epratuzumab inhibits the production of the proinflammatory cytokines IL-6 and TNF-alpha, but not the regulatory cytokine IL-10, by B cells from healthy donors and SLE patients. Arthritis Res Ther. 2015;17:185.

134. Anolik JH, Barnard J, Owen T, Zheng B, Kemshetti S, Looney RJ, et al. Delayed memory B cell recovery in peripheral blood and lymphoid tissue in systemic lupus erythematosus after $B$ cell depletion therapy. Arthritis Rheum. 2007;56(9):3044-56.

135. Wallace ZS, Mattoo H, Mahajan VS, Kulikova M, Lu L, Deshpande V, et al. Predictors of disease relapse in IgG4-related disease following rituximab. Rheumatology (Oxford).

2016;55(6):1000-8.

136. Collins M, Navaneethan SD, Chung M, Sloand J, Goldman B, Appel G, et al. Rituximab treatment of fibrillary glomerulonephritis. Am J Kidney Dis. 2008;52(6):1158-62.

137. Maritati F, Fenoglio R, Pillebout E, Emmi G, Urban ML, Rocco R, et al. Brief Report: Rituximab for the Treatment of Adult-Onset IgA Vasculitis (Henoch-Schonlein). Arthritis Rheumatol.

2018;70(1):109-14.

138. Comstock E, Kim CW, Murphy A, Emmanuel B, Zhang X, Sneller M, et al. Transcriptional profiling of PBMCs unravels $B$ cell mediated immunopathogenic imprints of HCV vasculitis. PLoS One. 2017;12(12):e0188314.

139. Comarmond C, Garrido M, Pol S, Desbois AC, Costopoulos M, Le Garff-Tavernier M, et al. Direct-Acting Antiviral Therapy Restores Immune Tolerance to Patients With Hepatitis C VirusInduced Cryoglobulinemia Vasculitis. Gastroenterology. 2017;152(8):2052-62 e2.

140. Lin W, Jin L, Chen H, Wu Q, Fei Y, Zheng W, et al. B cell subsets and dysfunction of regulatory $B$ cells in IgG4-related diseases and primary Sjogren's syndrome: the similarities and differences.

Arthritis Res Ther. 2014;16(3):R118.

141. Wallace ZS, Mattoo H, Carruthers M, Mahajan VS, Della Torre E, Lee H, et al. Plasmablasts as a biomarker for IgG4-related disease, independent of serum IgG4 concentrations. Ann Rheum Dis. 2015;74(1):190-5.

142. Wang YY, Zhang L, Zhao PW, Ma L, Li C, Zou HB, et al. Functional implications of regulatory B cells in human IgA nephropathy. Scand J Immunol. 2014;79(1):51-60.

143. Lafayette RA, Canetta PA, Rovin BH, Appel GB, Novak J, Nath KA, et al. A Randomized, Controlled Trial of Rituximab in IgA Nephropathy with Proteinuria and Renal Dysfunction. J Am Soc Nephrol. 2016.

144. Dahan K, Debiec H, Plaisier E, Cachanado M, Rousseau A, Wakselman L, et al. Rituximab for Severe Membranous Nephropathy: A 6-Month Trial with Extended Follow-Up. J Am Soc Nephrol. 2017;28(1):348-58. 
145. Rosenzwajg M, Languille E, Debiec H, Hygino J, Dahan K, Simon T, et al. B- and T-cell subpopulations in patients with severe idiopathic membranous nephropathy may predict an early response to rituximab. Kidney Int. 2017;92(1):227-37.

146. van den Brand J, Ruggenenti P, Chianca A, Hofstra JM, Perna A, Ruggiero B, et al. Safety of Rituximab Compared with Steroids and Cyclophosphamide for Idiopathic Membranous Nephropathy. J Am Soc Nephrol. 2017;28(9):2729-37.

147. Colucci M, Carsetti R, Cascioli S, Casiraghi F, Perna A, Rava L, et al. B Cell Reconstitution after Rituximab Treatment in Idiopathic Nephrotic Syndrome. J Am Soc Nephrol. 2016;27(6):1811-22.

148. Kim AH, Chung JJ, Akilesh S, Koziell A, Jain S, Hodgin JB, et al. B cell-derived IL-4 acts on podocytes to induce proteinuria and foot process effacement. JCI Insight. 2017;2(21).

149. Cho BS, Yoon SR, Jang JY, Pyun KH, Lee CE. Up-regulation of interleukin-4 and CD23/FcepsilonRII in minimal change nephrotic syndrome. Pediatr Nephrol. 1999;13(3):199-204. 150. Edwards JC, Szczepanski L, Szechinski J, Filipowicz-Sosnowska A, Emery P, Close DR, et al. Efficacy of B-cell-targeted therapy with rituximab in patients with rheumatoid arthritis. N Engl J Med. 2004;350(25):2572-81.

151. Weiner GJ. Rituximab: mechanism of action. Semin Hematol. 2010;47(2):115-23.

152. Dorner T, Lipsky PE. B-cell targeting: a novel approach to immune intervention today and tomorrow. Expert Opin Biol Ther. 2007;7(9):1287-99.

153. Ward E, Mittereder N, Kuta E, Sims GP, Bowen MA, Dall'Acqua W, et al. A glycoengineered anti-CD19 antibody with potent antibody-dependent cellular cytotoxicity activity in vitro and lymphoma growth inhibition in vivo. Br J Haematol. 2011;155(4):426-37.

154. (CALIBRATE) RaBfLN. NCT02260934.

155. (SYNBIOSe) SB-CliS. NCT02284984.

156. BLISS-BELIEVE AStEtEaSoBAiCWRtASWSLES-. NCT03312907.

157. Synergetic B-cell Immodulation in SLE.

158. Holden NJ, Williams JM, Morgan MD, Challa A, Gordon J, Pepper RJ, et al. ANCA-stimulated neutrophils release BLyS and promote B cell survival: a clinically relevant cellular process. Ann Rheum Dis. 2011;70(12):2229-33.

159. Mahevas M, Patin P, Huetz F, Descatoire M, Cagnard N, Bole-Feysot C, et al. B cell depletion in immune thrombocytopenia reveals splenic long-lived plasma cells. J Clin Invest. 2013;123(1):432-

42.

160. Vital EM, Kay J, Emery P. Rituximab biosimilars. Expert Opin Biol Ther. 2013;13(7):1049-62.

161. Chen D, Ireland SJ, Davis LS, Kong X, Stowe AM, Wang Y, et al. Autoreactive CD19+CD20-

Plasma Cells Contribute to Disease Severity of Experimental Autoimmune Encephalomyelitis. J Immunol. 2016;196(4):1541-9.

162. Eskandary F, Regele H, Baumann L, Bond G, Kozakowski N, Wahrmann M, et al. A Randomized Trial of Bortezomib in Late Antibody-Mediated Kidney Transplant Rejection. J Am Soc Nephrol. 2018;29(2):591-605.

163. trial T. NCT02102594.

164. Ratnasingam S, Walker PA, Tran H, Kaplan ZS, McFadyen JD, Tran H, et al. Bortezomib-based antibody depletion for refractory autoimmune hematological diseases. Blood Adv. 2016;1(1):31-5.

165. Jelinek T, Hajek R. Monoclonal antibodies - A new era in the treatment of multiple myeloma. Blood Rev. 2016;30(2):101-10.

166. Watkins MP, Bartlett NL. CD19-targeted immunotherapies for treatment of patients with non-Hodgkin B-cell lymphomas. Expert Opin Investig Drugs. 2018:1-11.

167. Amrouche K, Jamin C. Influence of drug molecules on regulatory B cells. Clin Immunol. 2017;184:1-10.

168. Wallin EF, Jolly EC, Suchanek O, Bradley JA, Espeli M, Jayne DRW, et al. Human T-follicular helper and T-follicular regulatory cell maintenance is independent of germinal centers. Blood. 2014;124(17):2666-74. 
169. Wei C, Anolik J, Cappione A, Zheng B, Pugh-Bernard A, Brooks J, et al. A new population of cells lacking expression of $\mathrm{CD} 27$ represents a notable component of the $B$ cell memory compartment in systemic lupus erythematosus. J Immunol. 2007;178(10):6624-33.

170. Dorner T, Shock A, Goldenberg DM, Lipsky PE. The mechanistic impact of CD22 engagement with epratuzumab on B cell function: Implications for the treatment of systemic lupus erythematosus. Autoimmunity Reviews. 2015;14(12):1079-86.

171. European Association for the Study of the Liver. Electronic address eee, Lampertico $P$, Agarwal K, Berg T, Buti M, Janssen HLA, et al. EASL 2017 Clinical Practice Guidelines on the management of hepatitis B virus infection. J Hepatol. 2017.

172. Molloy ES, Calabrese LH. Progressive multifocal leukoencephalopathy associated with immunosuppressive therapy in rheumatic diseases: evolving role of biologic therapies. Arthritis Rheum. 2012;64(9):3043-51.

173. Thiel J, Rizzi M, Engesser M, Dufner AK, Troilo A, Lorenzetti R, et al. B cell repopulation kinetics after rituximab treatment in ANCA-associated vasculitides compared to rheumatoid arthritis, and connective tissue diseases: a longitudinal observational study on 120 patients. Arthritis Res Ther. 2017;19(1):101.

174. Roberts DM, Jones RB, Smith RM, Alberici F, Kumaratne DS, Burns S, et al. Rituximabassociated hypogammaglobulinemia: incidence, predictors and outcomes in patients with multisystem autoimmune disease. J Autoimmun. 2015;57:60-5.

175. Merrill JT, Ginzler EM, Wallace DJ, McKay JD, Lisse JR, Aranow C, et al. Long-term safety profile of belimumab plus standard therapy in patients with systemic lupus erythematosus. Arthritis Rheum. 2012;64(10):3364-73.

176. Mok CC. Rituximab for the treatment of rheumatoid arthritis: an update. Drug Des Devel Ther. 2013;8:87-100.

177. Saze Z, Schuler PJ, Hong CS, Cheng D, Jackson EK, Whiteside TL. Adenosine production by human B cells and B cell-mediated suppression of activated T cells. Blood. 2013;122(1):9-18.

178. Venhoff N, Niessen L, Kreuzaler M, Rolink AG, Hassler F, Rizzi M, et al. Reconstitution of the peripheral B lymphocyte compartment in patients with ANCA-associated vasculitides treated with rituximab for relapsing or refractory disease. Autoimmunity. 2014;47(6):401-8.

179. von Borstel A, Abdulahad WH, Rutgers A, Land J, Stegeman CA, Heeringa P, et al. Increased CD38hiCD27+ Plasmablast Frequency in Remission Predicts Relapsing Disease in Granulomatosis with Polyangiitis Patients Arthritis Rheumatol. 2017;69 (suppl 10).

180. Morelon E, Lefrancois N, Besson C, Prevautel J, Brunet M, Touraine JL, et al. Preferential increase in memory and regulatory subsets during T-lymphocyte immune reconstitution after Thymoglobulin induction therapy with maintenance sirolimus vs cyclosporine. Transpl Immunol. 2010;23(1-2):53-8.

181. Song J, Xiao L, Du G, Gao Y, Chen W, Yang S, et al. The role of regulatory B cells (Bregs) in the Tregs-amplifying effect of Sirolimus. Int Immunopharmacol. 2016;38:90-6.

182. Heidt S, Hester J, Shankar S, Friend PJ, Wood KJ. B cell repopulation after alemtuzumab induction-transient increase in transitional B cells and long-term dominance of naive B cells. Am J Transplant. 2012;12(7):1784-92. 